\title{
POLÍTICA EXTERNA BRASILEIRA Capital social e discurso democrático na América do Sul
}

\section{Rafael Duarte Villa}

\section{Introdução}

Será possível falar em capital social em política externa? É bem conhecido que as pesquisas que agregaram evidências empíricas à idéia de capital social tratavam de temas de política nacional ou, no máximo, de política comparada (Almond e Verba, 1989; Putnam 1993, 1997; Locke, 2001; Fukuyama, 1995). Esses trabalhos têm ressaltado as condições nas quais é possível gerar capital social positivo e valores cívicos, além de enfatizar o estudo do processo pelo qual é possível transformar o capital social em capital político, ou seja, institucionalizar o capital social. Nessa linha, Putnam tem definido o capital social da seguinte forma: "características da organização social como confiança, normas e sistemas que contribuem para aumentar a eficiência da

Artigo recebido em junho/2005

Aprovado em dezembro/2005 sociedade facilitando as ações coordenadas" (1977, p. 177). No Brasil, o conceito de capital social tem orientado um bom número de trabalhos entre os quais pode-se destacar os de Baquero (2003), Boschi (1999) e Reis (2003).

O trabalho de Locke (2001) classifica duas linhas de literatura sobre a geração de confiança entre atores: uma de natureza sociológica e outra ligada às análises racionalistas econômicas. No primeiro caso, destacam-se o trabalho de Putnam (1993), que explica a maior eficiência institucional no Norte e no Centro em comparação com o Sul da Itália, considerando o estoque de capital social expresso em comprometimento cívico e tradições cívicas mais bem desenvolvidas. O segundo grupo é composto por teóricos como North (1990), Gibbsons (2001) e Hardin (2001), que têm como fonte principal o famoso trabalho de Robert Axelrod (1984), The evolution of cooperation, cujas premissas básicas são: a confiança tem por base o auto-interesse de longo prazo, ou "interes- 
se encapsulado", como denomina Hardin, e a expectativa positiva que decorre do cálculo de custos e benefícios entre atores maximizadores de utilidade. Nessa linha claramente racionalista, pequenos grupos de atores consideram vantajoso o estabelecimento de relações cooperativas se as interações cooperativas forem repetidas entre os atores e se a informação a respeito do comportamento passado dos atores for completa.

Para Locke, ambas as correntes apresentam três falhas básicas: 1) são estáticas, "porque assumem que padrões de associativismo e/ou de capital social - vistos por alguns como os pré-requisitos da confiança, fixos no tempo e no espaço" (2001, p. 256); 2) a maior parte da literatura é mecanicista "por tratar os pré-requisitos da confiança - sejam eles institucionais ou sociológicos como variáveis homogêneas binárias [...] ou as sociedades possuem as instituições 'certas' ou não as possuem. Ou elas possuem um estoque suficiente de capital social ou uma quantidade insuficiente dele" (Idem, p. 257); e 3) a literatura é "majoritariamente pessimista quanto às possibilidades de se criar confiança no contexto onde as condições favoráveis e/ou pré-requisitos de que eles supostamente dependem não estão dados" (Idem, p. 156). Pensando em um contexto doméstico, Richard Locke explora a questão da possibilidade de se criar confiança e de como fazê-lo (Idem, p. 25).

Mas será possível pensar em termos de "capital social" e "geração de confiança" ao considerar ações coletivas que envolvem política externa entre Estados? Caso afirmativo, como fazê-lo? Entendemos que, ao discutir temas como a "cooperação" e a "confiança" entre atores estatais em política internacional, embora não exista uma referência explícita, as teorias das relações internacionais apresentam elementos de aproximação com a teoria do capital social.

A corrente neo-institcionalista, também baseada no trabalho de Axelrod (1984), tem na teoria da reciprocidade de Robert Keohane um de seus principais expoentes. Segundo Keohane, que partiu da mesma lógica do auto-interesse como motivação primária para a cooperação entre atores, Axelrod "demonstra que a racionalidade da cooperação depende não só dos ganhos imediatos esperados pelos jogadores, mas tam- bém do que se denomina "sombra do futuro" (1993a, pp. 194-195), quer dizer, da incerteza. O dilema pelo qual os atores, nas suas relações estratégicas de cooperação, fazem a opção ou não por esta é compreendido por Axelrod num jogo seqüencial chamado de reciprocidade específica. ${ }^{1}$ A estratégia de reciprocidade específica usa a tática do "olho por olho". Isso significa que a um movimento cooperativo de um jogador $\mathrm{A}$ seguirá, em contrapartida, uma jogada cooperativa por parte de um jogador B; a deserção de A será seguida pela deserção de B. No entanto, a deserção pode criar incentivos para que outros atores se sintam prejudicados, o que origina uma pressão a favor da cooperação. Para Keohane,

[...] a virtude adicional à reciprocidade específica pode criar incentivos para que interesses, que de outra maneira seriam passivos dentro de seus países, se oponham a uma ação unilateral por parte de seus próprios governos. Em 1984, por exemplo, os granjeiros norte-americanos opuseram-se às cotas de aço se antecipando a represálias [externas] contra suas exportações agrícolas (1993a, pp. 197-198).

O autor, no entanto, não sugere que autointeresse e percepções de interesses comuns sejam incompatíveis. Como parte da literatura institucionalista tem mostrado, ambas as motivações são compatíveis, e o problema apresenta-se nas características conformadoras da anarquia internacional, assim como nas restrições que esta impõe para a cooperação (Balwin, 1993).

Uma segunda perspectiva no âmbito da teoria das relações internacionais próxima da categoria de capital social tem sido desenvolvida pelo pensamento pós-positivista da escola construtivista, especialmente nos trabalhos de Alexander Wendt (1992, 1995). Para esse autor, as identidades, positivas ou negativas, e/ou os interesses dos atores estatais são uma construção, e, "se repetidas com freqüência, essas operações recíprocas" geram conceitos relativamente estáveis de ajuda - "é essa interação recíproca que define nossas identidades e interesses" (1992, p. 405). Contudo, tais identidades não são estáticas, já que podem ser construídas e desconstruídas em novos movimentos interativos.

No campo das correntes construtivistas, a "confiança” é a base para a criação do que elas denomi- 
nam "comunidades pluralistas de segurança", conceito inspirado nos trabalhos de Karl Deutsch e outros (1957). O construtivismo tem definido as comunidades de segurança como "uma região transnacional composta de estados soberanos, em que as sociedades mantêm expectativas cofiáveis de mudança pacífica" (Adler e Barnet, 1998a, p. 30). É interessante ressaltar que uma "comunidade de segurança” apresenta quatro características básicas que também são parte do núcleo do conceito de "capital social":

1. Os atores compartem valores, identidades e significados.

2. A reciprocidade específica, uma característica que implica algum grau de interesse de longo prazo, assim como a geração de um senso de responsabilidade e obrigação em comum - em outras palavras, valores, identidades e significados chegam a ser uma "condição" de segurança nacional ou internacional (Idem, 1998b).

3. A construção de confiança mútua entre estados de uma região. Tal confiança alimenta expectativas de solução de conflitos que descartam os recursos de poder baseados na força (ou do tipo power-based) - as fronteiras dessa região não coincidem necessariamente com as fronteiras geográficas, uma vez que a criação de valores, identidades e significados comuns leva à noção de regiões cognitivas, ou seja, "o reconhecimento de que as comunidades se desenvolvem em torno de redes, interações e encontros face a face, que não dependem de habitar o mesmo espaço geográfico, reconceitualiza a idéia comum de região" (Idem). Um exemplo notável de fronteiras cognitivas é a aliança ocidental da Otan, como defendem autores como John Gerard Ruggie (1998).

4. As comunidades de segurança mesmo que baseadas na confiança entre parceiros estatais numa determinada região geograficamente contígua ou cognitiva não são incompatíveis com a realização do auto-interesse dos atores. Em outras palavras, o conceito de comunidade de segurança opera na mesma lógica descrita por Putnam (1993) para o capital social, ou seja, a partir do envolvi- mento de ações individuais em ações coletivas que geram redes de confiança recíproca, tendo um impacto não só na comunidade do agente, mas também para além das fronteiras da comunidade, posto que essas redes permitem a construção de virtudes cívicas ou de uma cultura cívica.

Finalmente, uma terceira perspectiva próxima à teoria do capital social tem sido pensada como uma saída de meio termo entre as análises positivistas (como as realistas) e as construtivistas. Nessa categoria destaca-se o trabalho organizado por Goldstein e Keohane, Ideas and foreign policy (1993), obra em que se pretende uma aproximação entre a conduta externa, movida pelas ou relativa às idéias, e aquela movida por interesses e poder. ${ }^{2}$ Os autores, fazendo uma autocrítica em nome do racionalismo, sobretudo do institucionalismo neoliberal e do neo-realismo, reconhecem as limitações das perspectivas teóricas racionalistas sobre o impacto das idéias nas políticas governamentais. Ao enfocar, principalmente, as variações dos constrangimentos exógenos (capacidades de poder) das unidades políticas, ponto comum a ambas às escolas, tanto o neo-realismo como o neoliberalismo cometem uma dupla falta - por um lado, assumir que as preferências e as crenças são dadas ou que podem ser remetidas à caixa preta do interesse nacional, por outro, relegar as idéias e as crenças à qualidade de epifenômeno ou a um papel periférico, em função do interesse dos atores.

No campo dos trabalhos empíricos que testam, na arena internacional, a geração de capital social, um dos pensadores mais marcantes do mainstream norte-americano das relações internacionais, John Ikenberry (2002), tem trabalhado com um argumento bem próximo dos estudos seminais de Almond e Verba (1989) - os quais apontam que uma das fontes da perdurabilidade da hegemonia norte-americana teria ligação com o fato de os Estados Unidos terem gerado, durante os anos do pós-Guerra Fria, uma cultura cívica transnacional baseada em duas fontes. A primeira reside no fato de que seu poder tem sido mais aceitável para o restante do mundo porque seu projeto é congruente com as forças mais profundas da modernização. A sincronia entre o estabelecimento dos Estados Unidos como uma super- 
potência liberal e global e os imperativos mais amplos da modernização no mundo criaram um vínculo funcional entre este país e o restante do mundo. A promoção do fordismo, da força de trabalho educada, de fluxos de informação e tecnologia e de progressivos e mais especializados sistemas sociais e industriais de organização são congruentes entre o modelo oferecido pelos norteamericanos e as demandas modernizantes tanto de aliados, como não-aliados. A segunda fonte diz respeito à existência de um modelo de identidade política norte-americana baseado num nacionalismo cívico e multiculturalista, o que parece ser de grande importância. Com efeito, os Estados Unidos praticariam um nacionalismo cívico e não um nacionalismo étnico.

Numa sociedade multicultural a identidade do grupo é subordinada a regras de direitos e a um credo de obrigações políticas; em outras palavras, raça, religião, língua ou etnicidade não são relevantes para definir os direitos do cidadão nem para definir sua inclusão no sistema político norte-americano. Assim, tal sistema rejeita a noção de cidadania ligada à idéia de que direitos e participação sejam vinculados à etnicidade. Isso suscita duas implicações importantes: 1) o modelo de nacionalismo cívico estimula a projeção dos Estados Unidos como projeto de sociedade a ser almejado, inclusive como modelo de organização no mundo pós-Estados; 2) tal modelo tende a criar uma fonte de identidade e cooperação com outros Estados ocidentais, uma vez que no senso comum haveria um favorecimento à coesão e à cooperação. Como o nacionalismo cívico está enraizado em ideais democráticos e regras de direito compartilhadas, ele fornece uma importante via de hegemonia branda. O caráter multicultural da identidade política norte-americana tende a reforçar o internacionalismo, isto é, uma visão liberal cosmopolita e pluralista, o que se traduziria na criação de uma identidade que tende a apoiar o instrumental na construção do multilateralismo internacional em bases mais pluralistas.

A visão de Ikenberry está muito próxima da de Thomas Risse(2002), segundo a qual existe uma comunidade de segurança ocidental liberal comandada pelos Estados Unidos - base da ordem estável contemporânea e da unipolariadade norte-americana. Três características poderiam definir tal ordem: (1) identidades e valores em comum; (2) política e economia em base transnacional e interdependência cultural; e (3) governança institucionalizada.

Não pretendemos fazer uma opção exclusiva por nenhuma destas três perspectivas - neo-institucionalismo de Keohane; construtivismo; e idéias somadas a interesses -, mas aproveitar alguns elementos que parecem eficientes para compreender e explicar os fatos analisados. O objetivo é investigar os efeitos das idéias democráticas e da democratização na formação de confiança entre países sul-americanos e o Brasil e como essas idéias influenciaram a geração de movimentos cooperativos recíprocos e de imagens positivas do poder de vizinhos sul-americanos sobre a política externa brasileira. Sustentamos o argumento de que o discurso democrático foi condição primária para a criação de confiança - a despeito do estoque de capital social negativo acumulado nos governos militares que precederam à redemocratização brasileira e apesar do "interesse encapsulado" implícito nas metas de política externa. Para investigar o efeito das idéias democráticas e da democratização como meio da política externa brasileira de criar confiança com vizinhos sul-americanos atentaremos para cinco categorias: (1) identidades compartilhadas; (2) auto-interesse ou interesses encapsulados; (3) idéias compartilhadas; (4) histórico de reciprocidade específica positiva; e (5) institucionalização de normas de autogovernança, como confiança, transparência e monitoramento.

Este estudo é dividido em quatro partes: na primeira seção mapeamos as condições que permitiram a formação das preferências pela agenda democrática como um meio de política externa; na segunda, estudamos as interações seqüenciais entre o Brasil e a Venezuela e o impacto de idéias democráticas e dos interesses como instrumentos de política externa para gerar capital social e confiança; na terceira, repetimos o mesmo procedimento para testar como é possível gerar capital social e confiança em matéria de segurança e desarmamento, tomando como base analítica o histórico de reciprocidades entre o Brasil e a Argentina nos últimos trinta anos; finalmente, fazemos um balanço mostrando algumas limitações para a política externa brasileira na geração de capital social positivo na América do Sul. 


\section{A formação da preferência pela agenda democrática}

No Brasil ainda são muito escassos trabalhos na área de política internacional que mapeiem relações causais entre conduta externa dos estados e democracia como ferramenta de política externa. De acordo com a bibliografia existente (cf. Soares de Lima, 2000; Santiso, 2002; Villa, 2003; Câmara, 1998), o conjunto de estudos tem se dirigido à análise de variáveis importantes, como as cláusulas democráticas no sistema interamericano e as determinantes domésticas e sistêmicas que orientam a promoção da democracia por parte da política externa brasileira. Por isso, nosso objetivo primeiro é apresentar algumas idéias referentes a processos de causalidade sobre a formação das preferências democráticas como recurso de política externa.

Partimos do pressuposto de que a formação da agenda democrática para a América do Sul como uma preferência soft que enfraquecia outras possibilidades baseadas prioritariamente em política de poder - foi condição para a geração de capital social positivo no Brasil e em seus vizinhos sul-americanos. Mas, como se formou essa preferência pela democracia como instrumento de política externa regional?

Os trabalhos de Goldstein e Keohane (1993), Peter Haas (1992) e Adler (1992), sustentam que, em contextos internacionais de incerteza, idéias são poderosos mapas que guiam a procura por novas formas de inserção internacional e adequação às novas condições emergentes, assim como podem induzir ao estabelecimento de novos padrões de comportamento e relacionamento entre Estados.

No sistema de polaridades definidas da Guerra Fria

[...] do ângulo do pensamento institucional, os argumentos sobre a presença institucional do Brasil tinham como ponto de partida necessário o sistema internacional que determinava escolhas claras, à medida que estava estruturado num conflito global: ou adotávamos a posição de um dos lados, ou alguma forma de neutralidade (Fonseca, 1998, p. 285).
Como reconhece um agente formulador da política externa brasileira, ao se enfraquecer esse sistema de polaridades definidas, algumas idéias passaram a ser um instrumento para esclarecer novas escolhas num contexto incerto e duplo "de riscos e possibilidades" (Amorim, 1994a). Em outras palavras, idéias surgiam como uma resposta da política externa brasileira às mudanças nas condições sistêmicas. Na perspectiva epistemológica, a introdução da variável sistêmica e seu impacto na conduta e nas escolhas de política externa configurariam aquilo que sugere o pensamento neo-realista e o institucionalismo neoliberal (Balwin, 1993; Grieco, 1993; Keohane, 1993b). Contudo, as idéias aparecem não tanto como uma variável dependente da estrutura, mas sim como uma expectativa endógena aos atores.

A formulação do road map democrático foi apresentada, então, como uma prioridade para setores vinculados à arena externa brasileira: "é absolutamente necessário ter um mapa das forças profundas que modelam a transição e que se revelam, ora explicitamente ora implicitamente, a cada negociação específica, a cada encontro bilateral, a cada reunião multilateral" (Lafer e Fonseca, 1994, p. 50). Com base nesse tipo de preocupação, que revelava incertezas sobre qual o caminho a seguir, um problema relevante para as agências formuladoras de política externa no Brasil passou a ser a formação da preferência dentro do leque de idéias disponíveis: ${ }^{3}$ "para compreender a formação das preferências, precisamos compreender quais idéias estão disponíveis" (Goldstein e Keohane, 1993, p.13).

É necessário compreender, também, quais as condições em que operam as idéias disponíveis. A identificação desse leque de idéias para os formuladores de política externa brasileira foi facilitada por três condições sistêmicas.

A primeira reside no fato de que o fim da Guerra Fria, fortemente marcado pela polarização ideológica, reduziu significativamente as opções valorativas disponíveis. A hipótese de alguns pensadores norte-americanos - que tiveram em Francis Fukuyama um mentor intelectual destacado sobre a universalização da forma institucional de democracia representativa euro-americana parecia, em princípio, irrefutável. A política também havia se globalizado via o valor da democracia ocidental liberal. Isto é, num mundo polarizado ideologica- 
mente, como aquele do período da Guerra Fria, valia a definição de Carl Schmitt (1992) de que a relação básica da política é a dicotomia amigo-inimigo. Contudo, na perspectiva analítica, com a globalização unidimensional da política na base da crença no valor universal da democracia ocidental, um dos campos da metáfora política de Schmitt (o inimigo) tende a desaparecer.

Mesmo com a crítica a esse tipo de pensamento - desconfiava-se que fosse uma justificativa ideológica para preparar a ação do hegemon no pós-Guerra Fria (cf. Amorim, 1994b, pp. 133-134) não houve dúvida de que a variação dos constraints valorativos sistêmicos (mudança de duas alternativas doutrinárias para uma só) agiram como uma baliza cognitiva, na medida em que fornecia aos decision makers internos parâmetros para sondar qual era o grau de manobra disponível para uma potência média como o Brasil, caso tentasse uma ação menos padronizada internacionalmente do ponto de vista ideológico. A evidência dos fatos levou, assim, em início dos anos de 1990, a que o discurso diplomático constatasse "o amplo consenso em torno da superioridade da democracia representativa" (Amorim, 1994a, p. 24, grifos nossos).

A segunda condição diz respeito à preferência pela democracia como instrumento de política externa, que também foi influenciada por processos estruturais operados no sistema interamericano desde a segunda metade dos anos de 1980 e, principalmente, pela geração de um sistema normativo de cláusulas democráticas na Organização dos Estados Americanos (OEA). ${ }^{4}$ Nessa direção, alguns estudos vêm apontando o surgimento, no sistema interamericano, de um regime internacional democrático que guia as expectativas e cria incentivos de cooperação para os atores (Goldberg, 2001) e de um conceito de defesa coletiva da democracia (Farer, 1996). A institucionalização dessas duas noções teóricas iniciou-se em meados da década de 1980, quando o Protocolo de Cartagena das Índias introduziu, como novos objetivos da OEA, a promoção e a consolidação da democracia no continente, respeitando o princípio da não-intervenção. Um passo firme foi dado em 1991, no chamado Compromisso de Santiago do Chile, que produziu a Declaração de Defesa Coletiva da Democracia e a Resolução 1080 ou "cláusula democrática" - meca- nismos normativos que prevêem a suspensão do sistema interamericano em países onde exista quebra da ordem constitucional e institucional democrática. A resolução 1080 foi aplicada durante a década de 1990 no caso de quatro Estados membros: Haiti (1991), Peru (1992), República Dominicana (1994) e Paraguai (1996), havendo ainda um pedido de aplicação no caso das eleições peruanas de 2000, no regime de Alberto Fujimori. Passo mais decisivo ainda foi a aprovação da Carta Democrática pelos países do continente, em setembro de 2001.

Além disso, os países sul-americanos haviam reafirmado o "compromisso democrático" nas duas experiências integracionistas da região. No caso dos países do Mercosul, o sistema de cláusulas democráticas foi formalizado pelo Protocolo de Ushuaia, de julho de 1998, e no caso da Comunidade Andina (CAN), pelo Protocolo Adicional ao Acordo de Cartagena sobre "O Compromisso da Comunidade Andina com a Democracia". 5

A terceira e última condição sistêmica referese à aceitação normativa da idéia de democracia como "valor universal dominante" que ajudou a estabelecer entre as elites brasileiras o consenso em torno dos vínculos causais entre identidade democrática, poder regional e desenvolvimento. ${ }^{6}$ Essa percepção é consistente com a hipótese de que as relações causais entre idéias e fatos "derivam sua autoridade do consenso de elites reconhecidas" (Goldstein e Keohane, 1993). Tal mapa cognitivo foi percebido (e reconhecido) pelas elites brasileiras em coerência com a tradição de autonomia do país (qualquer que for o qualificativo aplicado a essa autonomia) e politicamente mais viável que aquele explicitado durante os anos do governo Collor de Mello (o chamado paradigma modernização pela dependência), que supunha uma volta ao paradigma americanista e um certo grau de alienação da soberania nacional (cf. Soares de Lima, 1994).

Dessa maneira, a sustentação da democracia como mapa do caminho já aparecia, em início dos anos de 1990, fortemente ligada à crença de que era muito importante reconhecer a "interdependência complexa" entre idéias e interesses. Essa interdependência sugeria uma releitura da hipótese dos "3D" do embaixador Araújo Castro - idéia formulada em meados dos anos de 1960, em que a missão das Nações Unidas, e do Brasil nesta 
organização, passava pela realização de três metas: desarmamento, desenvolvimento e descolonização. Nas palavras de formuladores de política externa contemporânea, a atualização da tese dos "3D" enfatiza os conceitos de democracia, desenvolvimento e desarmamento, "com seus desdobramentos nas áreas de Direitos Humanos, Meio Ambiente e da Segurança Internacional" (Amorim, 1994a, p. 21). Foram essas idéias e valores que forneceram aos formuladores de política externa as coordenadas regulatórias do mapa para a inserção do Brasil no mundo das polaridades indefinidas que se abria com o fim da Guerra Fria.

Esses três fatores sistêmicos forneceram uma explicação eficiente das motivações agregadas em torno da idéia de democracia como meio de ação política externa e dos cursos de ação a serem desenvolvidos. Serviram também como argumentos explicativos da escolha feita. A política externa é uma das dimensões políticas nas quais é preciso, com mais freqüência, explicar as razões da escolha.

De fato, pela sua própria natureza, a política externa se sustenta, talvez mais do que outras políticas de Estado, em procedimentos explicativos já que vive também de atitudes simbólicas que buscam exprimir ideologicamente a globalidade dos interesses nacionais (Fonseca, 1998, p. 267).

Assim, a idéia de que existiam certos constraints valorativos universais que agiam como marcos regulatórios de um novo mainstream de relações internacionais serviu como metodologia explicativa da prioridade dada ao curso de ação em face da "globalidade dos interesses nacionais".

Qual é a influência do tipo de ação que privilegia idéias democráticas - no sentido de atingir outras metas, tais como confiança em relação a seus vizinhos - e imagem positiva regional? A atuação da política externa gera imagens ambíguas quanto às motivações brasileiras regionais, porque algumas identidades negativas do passado continuam a prevalecer. No entanto, o marco democrático em que se sustenta a ação política externa tem operado como um importante instrumento para desconstruir o estoque de capital social negativo preexistente até a chegada dos governos democráticos em meados da década de 1980. Mapeadas as condições nas quais deu-se a formação das preferências por uma agenda democrática como meio de política, resta saber como foi operacionalizado o discurso democrático na geração de capital, confiança e melhoria da imagem entre vizinhos sulamericanos. Os casos das relações diplomáticas com a Venezuela e com a Argentina (neste último em torno de políticas de segurança e desarmamento) servirão para ilustrar adequadamente essa questão.

\section{Relações Brasil-Venezuela: das imagens negativas à cooperação estratégica}

O caso da Venezuela é significativo, por várias razões, para mostrar como se pode construir capital social positivo entre atores estatais onde ele não existe. O Brasil comparte com a Venezuela, fronteiras da ordem de $2.199 \mathrm{~km}$. Alguns autores (Cervo, 2002; Visentini, 1995; Ramos, 1995) defendem que talvez a relação bilateral mais sólida que o Brasil mantém hoje com seus vizinhos sul-americanos seja com esse país. Porém, durante os governos militares a Venezuela, como de resto quase todos os vizinhos sul-americanos, abrigavam identidades negativas sobre o Brasil. Lembremos que a literatura geopolítica e militar de intelectuais como Couto e Silva (1967), Terezinha de Castro (1976) e Correa Rocha (1965), assim como "O desastrado discurso feito por Richard Nixon em 1971 na Venezuela, afirmando que para onde o Brasil se inclinasse o resto do continente faria o mesmo" (Shiguenoli, 1999, p. 85) haviam feito estragos na imagem e na percepção que uma boa parte dos países sul-americanos tinham do Brasil, atribuindo-se ao Itamarati motivações subimperialistas e expansionistas baseadas em política de poder. No caso da Venezuela, um destes autores (Correa Rocha, 1965) chegou a conceber a hipótese pela qual o Brasil teria fixado sua fronteira norte pelo Mar Caribe, objetivo para o qual o autor propõe uma divisão pela metade das Guianas com a Venezuela. Na verdade esse tipo de proposta em vez de agradar a Venezuela alimentava mais temores do que confiança nas elites deste país.

Além das desconfianças geopolíticas existiam também causas políticas. Não é de hoje que os governos venezuelanos tentam usar o petróleo 
como recurso para alimentar uma pretensa liderança regional em áreas da América Latina, como nos países andinos, na América Central e no Caribe. Essa pretensão era já muito marcante durante o primeiro governo do social-democrata Carlos Andrés Pérez (1974-1979), período em que os preços do petróleo atingiram altas cotações mundiais. O chamado "milagre brasileiro", junto com a política pragmática externa do governo Geisel de diversificar relações comerciais e políticas independentemente da natureza ideológica dos países, também era motivo de desconfiança por parte das elites venezuelanas, que anteviam disputas com o Brasil pela liderança nessas regiões. Finalmente, entre as motivações políticas, ao contrário do projeto de autonomia política do governo brasileiro diante dos Estados Unidos (ou autonomia pela distancia, como se denominou o paradigma que orientou a política externa brasileira desde inícios dos anos de 1970 até finais da década seguinte), a política externa venezuelana, durante quase todo o século XX, sempre definiu como estratégica a parceria política com os Estados Unidos.

Como foi possível transformar relações de desconfiança em relações de confiança em que pese esse enfoque acumulado de capital social negativo na época da redemocratização? A reconstrução do processo histórico de reciprocidade específica positiva permitirá compreender como isso foi possível. Naquele quadro de desconfianças e imagens negativas, o Brasil tentou uma primeira ação cooperativa com a Venezuela ao apoiar a política petrolífera de preços altos, que reforçava o discurso da diplomacia venezuelana de valorizar as matérias-primas do Terceiro Mundo. Em compensação, a esse primeiro movimento cooperativo a Venezuela acertou com o Brasil convênios de cooperação em abril de 1978 nos ramos do petróleo, da petroquímica, da mineração e da siderurgia e, nesse mesmo ano, aceitou que a existência de acordos regionais como o Pacto Andino, de natureza econômica, não eram incompatíveis com acordos de cunho político sobre a administração de recursos naturais, criando-se, assim, condições para a assinatura do Tratado de Cooperação Amazônica, de iniciativa brasileira.

O jogo seqüencial de ações cooperativas e de reciprocidade manteve-se nos anos de 1980, respondendo o Brasil positivamente a uma velha proposta venezuelana, qual seja, a criação de uma multinacional latino-americana do petróleo, a Petrolatina. Também não é de hoje que a diplomacia venezuelana sustenta esse objetivo. ${ }^{7}$ O Brasil assinou em Caracas, em 1981, em conjunto com a Venezuela e o México, um protocolo para dar início a essa idéia. Embora o projeto da Petrolatina permanecesse engavetado nos cofres das chancelarias desses países até ser resgatado pela administração Chávez, o gesto diplomático brasileiro foi um importante passo para começar a mudar a identidade negativa do Brasil subimperialista perante seu vizinho venezuelano. Em outras palavras, as ações de reciprocidade específica nesta primeira fase fizeram-se na base da tolerância e do estímulo de interesses regionais, especialmente do apoio do Brasil a projetos regionais venezuelanos baseados no seu poderio petrolífero. Também esse tipo de reciprocidade reforçava, no plano dos atores sociais, os empresários, já que a aproximação entre ambos os países procurava criar condições para o desenvolvimento de projetos empresariais destinados a "robustecer o núcleo central das economias nacionais" (Cervo, 2001, p. 9).

Com a redemocratização brasileira iniciada no governo de José Sarney, uma nova idéia toma corpo, a de que a inserção mundial competitiva só seria possível por meio da integração regional sulamericana. Isso supunha que os países sul-americanos deixassem de pensar em seus modelos de desenvolvimento como passíveis de serem atingidos na visão nacional-desenvolvimentista, de "voltados para dentro", para coordenar ações coletivas e cooperativas regionais. Um mapeamento do discurso diplomático de decision makers de política externa desde o governo Sarney permite conferir uma constante: a percepção da América do Sul como prioridade da política externa brasileira (cf. Cardoso, 1993, p. 6; Amorim, 1994a, p. 16; Lafer, 2001b, p. 2; Silva, 2003, ou nas palavras de Lafer, a percepção de uma "força profunda da política externa brasileira" (2001b, p. 2). A construção desse significado permitiu que alguns autores afirmassem que ao longo de sua história o Brasil foi desenvolvendo a dupla identidade de país em desenvolvimento e país sul-americano. "Mas a verdade é que foi preciso que essa dupla identidade, hoje tão óbvia, fosse sendo construída no discurso e na 
auto-imagem dos brasileiros ao longo do século XX" (Lamazier, 2001, p. 51). Assim, no discurso da política externa brasileira contemporânea, sobretudo com a defecção da tão próxima política externa mexicana, hoje em dia, do Nafta e dos Estados Unidos, houve um esforço sistemático dos governos brasileiros, desde Itamar Franco, "em redefinir a cooperação regional em termos de América do Sul antes que [em termos] de uma identidade Latino-americana " (Hurrel, 1998, p. 257).

A partir do governo Sarney, passa-se a explorar fortemente o caminho integracionista sul-americano, tendo sido definida a Venezuela pela fronteira norte e a Argentina pela fronteira sul como as duas relações estratégicas a serem cultivadas para atingir esse objetivo. Instâncias de comportamento confiável começaram a ser seladas quando o presidente Sarney conseguiu promover a idéia entre seus pares venezuelanos de que o pathway integracionista era o melhor caminho para atingir três objetivos: desenvolvimento nacional, defesa da democracia e inserção competitiva internacional. Ainda durante o governo Sarney, o governo brasileiro assinou, em 1996, os Protocolos de Cooperação com a Argentina de Raul Alfonsin (1984-1988), e, com a Venezuela, durante o governo do socialdemocrata Jaime Lusinchi (1984-1988), o Protocolo de Caracas, em 1987, a partir dos quais se pretendia fazer deslanchar os processos integracionistas na América do Sul.

O reforço normativo que serviu como mapa cognitivo da estratégia brasileira de aproximação com vizinhos como Argentina e Venezuela foi o argumento de formuladores de política externa dos anos de 1990, segundo o qual o Brasil estava politicamente amadurecido para evoluir das "clássicas fronteiras [para] modernas fronteiras de cooperação" (Lafer, 2001b, p. 2). ${ }^{8}$ Destaca-se no conceito de "fronteiras de cooperação" primeiramente a mudança nas formas de produção e representação do significado do espaço brasileiro como algo não só instrumental, mas também substantivo em face dos interesses regionais de integração regional. Em segundo, o conceito é consistente com a crença nos

[...] investimentos no soft power da credibilidade realizados pelo país no correr da década de 90 , ao tratar de maneira construtiva - pela participa- ção e não pela distância - os "temas globais" que se inseriram, em novos termos, na agenda internacional pós-guerra fria (Lafer, 2001b. p. 2).

O mais importante a destacar é que nesta fase se consegue desconstruir a primeira das identidades negativas que mais criavam obstáculos para uma ação cooperativa entre a Venezuela e o Brasil, a saber, a de que o Brasil seria um país com motivações subimperialistas. "A imagem de um Brasil expansionista, hegemônico e dominador modificou-se drasticamente e as expectativas positivas afloraram" (Cervo, 2001 p. 9).

Porém, ainda restava desconstruir mais duas imagens: primeiro, a de que a liderança venezuelana no processo de integração regional andino era incompatível com a liderança regional integracionista sul-americana promovida pelo Brasil; e, segundo, a idéia de que as metas de política externa venezuelana eram mais compatíveis com uma política de aliança estratégica com os Estados Unidos do que com o Brasil, que ocupava um lugar periférico no olhar das elites venezuelanas. Esses dois objetivos foram trabalhados intensamente durante toda a década de 1990 pela política externa brasileira, desde o segundo governo do democrata-cristão Rafael Caldera e na administração Hugo Chávez. Observemos, então, como se deu esse processo diplomático.

Durante a administração de Itamar Franco no Brasil e de Rafael Caldera na Venezuela firmaram-se algumas das bases que compatibilizariam o projeto brasileiro de integração sul-americana com o projeto de integração sub-regional andino e de desenvolvimento nacional venezuelano. Esse projeto tinha por base três eixos de ação: desenvolver ações de integração fronteiriça e energética; desenvolver os fluxos bilaterais de comércio; e finalmente, investimento entre ambos os países, com proveito para os setores empresariais e criação de uma zona de livre comércio sulamericana.

O primeiro eixo - integração de fronteiras teve início com o reforço de políticas de povoamento em estados como Amazonas e Roraima, do lado brasileiro, e estados como Amazonas, Delta Amacuro e Bolívar, do lado venezuelano. Em ambos os lados das fronteiras comuns, os dois países desenvolveram políticas recíprocas e comple- 
mentares. À iniciativa brasileira do Programa Calha Norte, a Venezuela responderia, em meados dos anos de 1990, com o programa Prodesur. Ambos tinham objetivos em comum, tais como a melhoria da qualidade de vida das populações locais, a proteção do meio ambiente e o desenvolvimento da potencialidade econômica das regiões fronteiriças. Um empreendimento cooperativo de grande envergadura na integração física foi realizado no segundo mandato do presidente Fernando Henrique Cardoso. Ainda, foi reinaugurada a rodovia BR174, cujo trecho Manaus-Santa Helena de Uairén (primeira cidade fronteiriça venezuelana), liga o Brasil a Caracas. A Venezuela já havia feito sua parte inaugurando a BV-8, pela qual se fornece energia elétrica a Boa Vista, advinda das usinas do Rio Caroní venezuelano. Os interesses do Brasil neste mecanismo de integração física são evidentes: inserção de produtos no mercado venezuelano e de escoamento de produtos brasileiros pelos portos caribenhos da Venezuela, como La Guaira e Puerto Cabello, localizados ao norte deste país. De outra parte, desenvolveu-se uma política de integração energética bastante assertiva nas relações entre a Venezuela e o Brasil. As estatais de eletricidade - Eletrobras do Brasil e Edelca da Venezuela - vêm aproveitando o fato de a Venezuela ter algumas de suas principais usinas hidrelétricas instaladas na região sul - na fronteira com o Brasil - para, desta maneira, poder abastecer de energia os estados brasileiros dessa região, como Roraima, Amazonas e Amapá.

Quanto ao segundo eixo - fluxos bilaterais de comércio -, desde 1995 a promoção dos fluxos comerciais e de investimento e as compras de petróleo da Venezuela vêm aumentando significativamente, já superando, hoje, a Argentina entre os fornecedores latino-americanos. Os fluxos comercias incrementaram-se entre 1988 e 1995 a uma taxa promédio interanual de $8,2 \%$, registrando-se uma taxa interanual positiva para a Venezuela de $27,4 \%$ e, portanto, uma balança comercial positiva para este país (Cisneros et al., 1998, p. 9. Em contrapartida, faz parte da estratégia venezuelana atrair o Brasil como sócio de investimentos na Corporação Andina de Fomento (órgão financiador da Comunidade Andina de Nações). Nesse sentido, a Venezuela e o Brasil assinaram, durante o primeiro ano do governo Lula, um acordo guarda-chuva que inclui o aumento do fluxo de comércio, investimentos no setor petroquímico, compra e venda de tecnologias e outros tópicos. Porém,

O acordo guarda-chuva tem outras implicações e derivações. O Brasil, via BNDES, deverá aumentar sua presença como acionista da Corporação Andina de Fomento (CAF), banco de desenvolvimento dos países andinos, e chegar a $20 \%$ de participação no principal agente de investimento do Hemisfério Sul. Total do desembolso brasileiro: US\$ 400 milhões em dois anos. Cada país-membro da CAF pode financiar até quatro vezes o seu aporte para aplicações no próprio país. No caso, US\$ 1,6 bilhão. Se for projeto binacional, a aplicação pode multiplicarse por oito - ou US\$ 3,2 bilhões. Ao governo a CAF faz chegar sua intenção de investir US\$ 25 bilhões em toda a região nos próximos quatro anos" (Carta Capital, 2003, p. 32).

O terceiro eixo - criação de uma zona de livre comércio sul-americana - atingiu dinamismo acentuado, sobretudo a partir da administração Hugo Chávez, tendo como resultado um aumento sem precedentes da confiança entre esses dois países, além de operar um câmbio substancial sobre as alianças estratégicas tradicionais da Venezuela em política externa. O Brasil seria um dos países que passaria a ocupar um lugar estratégico nas relações externas da Venezuela. Lembremos que desde o século XIX as desconfianças em relação à política externa do Brasil sempre foram uma espécie de constante. O próprio Bolívar, naquele século, não incluiu o Brasil nos seus projetos da Gran Colômbia. E com o início da fase petrolífera nos anos de 1920, a prioridade em política externa - para a Venezuela - sempre foram os Estados Unidos.

Assim, uma das mudanças mais significativas nas relações de cooperação Brasil-Venezuela tem a ver com o lugar do Brasil na política externa venezuelana: o país passou a ocupar um lugar estratégico no planejamento da política externa venezuelana. Essa inflexão foi operada na base das possibilidades que os projetos de integração sul-americana ofereciam para a Venezuela. Em que pese desconfianças iniciais de que uma aproximação mais estreita com o Mercosul veria diluídas as tentativas integracionistas da região andina, o Brasil conseguiu atrair a Venezuela para seus 
projetos sul-americanos e com isso conseguiu uma redefinição positiva nos planos da política externa venezuelana.

A diplomacia comercial venezuelana, seguindo uma política de continuidade iniciada na segunda gestão de Rafael Caldera (1994-1998), deslocou seu interesse integracionista para a "fachada amazônica", especialmente no que se refere ao aprofundamento de seus vínculos comerciais, energéticos e políticos com o Brasil e com o Mercosul. "Registre-se que o ex-Presidente Fernando Henrique Cardoso acolheu e deu seguimento ao desejo de Chávez de mudar o olhar da elite venezuelana: mirar o Cruzeiro do Sul e não a Estrela Polar" (Carta Capital, 2003). ${ }^{\text {? }}$

Atualmente, o relacionamento entre Venezuela e Brasil é favorecido pelo entusiasmo da administração Chávez de integrar o Mercosul com a Comunidade Andina, como reconhece abertamente um documento oficial da chancelaria venezuelana, "especialmente pela significação estratégica do Brasil e pelas aspirações nacionais [da Venezuela] de ingressar no Mercosul" (Ministério de Relaciones Exteriores de Venezuela, 2005). Nesse sentido, seguindo a seqüência inaugurada por Bolívia e Peru, a Venezuela transformou-se, durante a última Reunião de Cúpula do Mercosul (julho de 2004), no terceiro país da Comunidade Andina de Nações (CAN) a ser admitido como membro associado ao Mercosul. A opção preferencial da Venezuela pelo Brasil foi muito bem resumida numa frase de conteúdo simbólico relevante do presidente venezuelano, em que afirma: "os bons negócios a gente reserva para os amigos. O nosso amigo é o Brasil" (Carta Capital, 2003, p. 30).

Comentando estas amplas coincidências entre ambos países, Amado Luiz Cervo, resumiu assim o relacionamento diplomático:

Com efeito, em que pesem diferenças de estilo na ação externa, nenhum outro país da América do Sul apresenta relativamente ao Brasil, no início do milênio, tantas variáveis comuns na sua visão do mundo e em sua estratégia externa quanto a Venezuela. A convergência se estabelece em torno dos seguintes parâmetros: a) o conceito de globalização assimétrica como correção ao conceito de globalização benéfica; b) o conceito político e estratégico da América do Sul; c) o reforço do núcleo central robusto da economia nacional como condicionante da interdependência global; d) a prévia integração da América do Sul como condicionante da integração hemisférica; e) a percepção da nocividade da Alca, caso se estabeleça sem os condicionantes anteriores e sem a reciprocidade comercial efetiva; f) reservas ante o aspecto militar do Plano Colômbia; g) o repúdio a qualquer presença militar norte-americana e a seus vôos na Amazônia; h) a decisão de não privatizar o setor petrolífero (2001 p. 19).

Ressalta também Cervo que durante as administrações Caldera, Chávez e Cardoso, de 1994 ao presente, "o empenho pessoal dos chefes de Estado foi o motor principal da cooperação que engrandeceu nas esferas da ação política e econômica" (2001, p. 21).

Um fato que sem dúvida reforçou o estoque de capital social acumulado entre ambos os países foi a atitude do Brasil na crise política venezuelana durante os anos da administração Chávez, especialmente com a condenação do breve golpe de Estado que derrubou Hugo Chávez em abril de 2002 (ainda no governo Fernando Henrique Cardoso). A proposta do simbólico Grupo de Amigos da Venezuela, sob a iniciativa do governo, Lula buscava resguardar uma política de Estado que tinha sido construída ao longo de mais de duas décadas e na qual a política externa brasileira foi capaz de transformar três identidades negativas enraizadas na percepção das elites venezuelanas (expansionismo, desconfiança diante dos planos de integração brasileira e uma visão periférica do Brasil na política externa venezuelana) em empreendimentos concretos e positivos de confiança nesses três aspectos.

O caso venezuelano mostra que é possível construir estoques de confiança entre atores estatais em áreas nas quais ainda não existam. No entanto, o Brasil ter priorizado o processo de integração no Cone Sul na década de 1990 e o fato de que as relações entre o Brasil e a Venezuela já eram bastante cooperativas até o final da década de 1980 tornaram os dois países convergentes a partir do governo de Rafael Caldera (1994-1998) e mais plenamente a partir do governo de Hugo Chávez, empossado em 1999. Como foi possível que atingissem esse ponto de cooperação, levando em conta que, até o final dos anos de 1970, prevaleciam fortes percepções de desconfiança? Pretendemos analisar esse resultado a partir de três ele- 
mentos: identidade, interesses encapsulados e idéias compartilhadas.

Quanto à identidade, deve ser destacado que a diplomacia brasileira compreendeu bem, na sua estratégia de aproximação com a Venezuela, os elementos que definem a identidade da política externa venezuelana e a necessidade de tornar congruente essa identidade com a sua própria. Foi isso que permitiu uma seqüência de movimentos cooperativos que não foram, em nenhum momento, incompatíveis com os "interesses encapsulados". Mas os estudiosos da política externa da Venezuela destacam que ao longo dos últimos cinqüenta anos dois foram os elementos que caracterizaram a identidade da política externa venezuelana: a inserção petrolífera internacional do país e a defesa da democracia (Romero, 2002; Villa, 2004).

O Brasil conseguiu conciliar de maneira eficaz sua identidade de país em desenvolvimento e sul-americano com sua compreensão de que, para a Venezuela, em qualquer tempo seria vital a defesa de uma política elevada dos preços de petróleo em razão de sua dependência fiscal a esse recurso. Foi assim que procedeu a diplomacia brasileira em finais da década de 1970, o que se manteve no governo de Chávez, que fez da recuperação dos preços internacionais do petróleo sua principal meta externa. Em contrapartida, o Brasil conseguiu obter importantes vantagens em termos de integração física, energética, comercial e em termos de investimentos. Na administração Chávez, a balança comercial, que era negativa em relação ao Brasil até finais da década de 1990, transformou-se em positiva, e empresas brasileiras, como as de cerveja e empreiteiras, fazem hoje investimentos importantes na Venezuela. Esse argumento demonstra que a confiança gerada pela reciprocidade específica e positiva não é isenta da procura de interesses que levem a ganhos mútuos.

Em relação aos interesses encapsulados, é possível creditar o aumento da confiança da Venezuela, com o Brasil e com o Mercosul, a comportamentos estratégicos "encapsulados": a Venezuela fez da diversificação das exportações em proporções equilibradas para diferentes mercados uma estratégia adequada, na medida em que tornou o país menos dependente de um único mercado e, portanto, menos vulnerável às contingências de mercado dos Estados Unidos. ${ }^{10}$. Como sustentado por Ramos "é possível afirmar que a nova integração entre o Brasil e a Venezuela guarda em si duas mensagens: uma selecionada e uma secundária" (1995, pp. 103 e 105). Na mensagem selecionada "O interesse venezuelano aparece com a possibilidade de se solucionar crises econômicas internas e de se diminuir a dependência e a dívida externa" (Idem, ibidem). Na opção secundária, a integração venezuelana com o Brasil "reveste-se de potencialidades desagregadoras, restos do reflexo do que teria representado o Brasil para as nações vizinhas durante determinados momentos da história latino-americana: um país com pretensões hegemônicas" (Idem, ibidem). Em reciprocidade, como afirmado por um estudioso da história cultural brasileira, a Venezuela responderia positivamente "às aspirações legítimas do Brasil em ocupar posição de influência no âmbito internacional dadas as suas dimensões" (Mendible, 1995).

Quanto às idéias compartilhadas, as estreitas relações bilaterais construídas entre a Venezuela e o Brasil durante a década de 1990 tiveram como ponto de interseção a visão recíproca de a que estabilidade institucional democrática é "condição essencial para o fortalecimento da integração regional" ("Comunicado de Brasília", 2000, p. 128). Essa visão é compatível com a segunda característica da identidade da política externa venezuelana - defesa da democracia. Assim, os interesses foram acompanhados por idéias compartilhadas, especificamente sobre a democratização do poder. Nesse sentido, a idéia do fortalecimento das instituições democráticas procura o duplo objetivo de um institutional building democrático doméstico e de um institutional building democrático regional.

Um fator que reforçou a formação das convergências entre o Brasil e a Venezuela como recurso de política externa foi o argumento da democratização do sistema internacional tão recorrente desde o final dos governos militares, o que coincidia com os desejos de democratização interna. Consistente com sua identidade de país democrático, a Venezuela desde os anos de 1960 pregava a doutrina Betancourt ${ }^{11}$ de não reconhecimento de governos autoritários, mas de governos eleitos mediante normas constitucionais e pela vontade popular. Por outro lado, a democratização no Brasil foi calibrada por decisores da política externa e por suas elites como um elemento domésti- 
co útil para a convergência de identidades positivas com seus vizinhos sul-americanos, e isto foi importante no caso da Venezuela. Como sustenta Fonseca:

A identidade modela-se historicamente. Há momentos em que coincidem as transformações internacionais e as internas como ocorreu claramente com a democratização. O sistema ocidental fecha o espaço para o autoritarismo e, internamente, as forças sociais contestam o regime (1998, pp. 275-276).

Tal convergência de identidades era consistente com a idéia de que a existência de um conjunto de valores universais, ou mapa cognitivo, para a conduta da política externa deveria ser tomado como marco regulatório normativo, em relação ao qual metas de desenvolvimento do país eram passíveis de serem atingidas. Esse discurso doutrinário foi bastante veiculado pela diplomacia durante toda a década de 1990, tal como sustentou o então p presidente Cardoso: "O Brasil que entra no século XXI é um país cujos objetivos prioritários de transformação interna, de desenvolvimento, estão em consonância com os valores que se difundem e se universalizam no plano internacional" (2000, p. 6).

Enfim, a idéia democrática como recurso de política externa permite adiantar a conclusão de que é possível criar capital social positivo entre Estados quando concepções normativas cooperativas do mundo são compartilhadas por atores estatais. Esse impacto na conduta externa dos países pode ser compreendido pela premissa de Schumpeter (1984), segundo a qual ao analisarmos os comportamentos e as estratégias dos atores políticos a democracia aparece como um método prioritário quando os atores participantes de um conflito têm como intuito final resolver o problema de forma a tolerarem as posições um do outro e a chegarem a uma solução democrática. Esse nos parece ter sido o caso das relações diplomáticas entre o Brasil e a Venezuela nos anos da redemocratização brasileira. A condição schupemteriana torna possível um desmanche teórico da idéia dos neorealistas (Grieco, 1993; Mearsheimer, 2001) de que a cooperação entre atores estatais é incompatível com o auto-interesse. Em outras palavras, confian- ça e auto-interesse são compatíveis se este é mediado por concepções de mundo cooperativas.

Vejamos então como é possível gerar capital social entre atores estatais no campo da política de armamento e segurança, entendidos pela teoria realista como o núcleo duro das metas dos Estados. Seria muito difícil estabelecer arranjos cooperativos, já que o desarme significaria uma espécie de comportamento irresponsável do estadista porque o Estado ficaria a mercê da política de poder de Estados concorrentes. No entanto, de acordo com estas percepções racionalistas que frisam a desconfiança entre atores, é possível sustentar que foi possível construir a confiança entre o Brasil e os vizinhos sul-americanos sobre tais variáveis hard core, especialmente na questão da não proliferação de armas no plano regional, da cooperação militar e das políticas de segurança.

\section{Relações Brasil-Argentina: capital social na democratização}

Como já demonstramos anteriormente, os vizinhos sul-americanos por décadas têm enxergado o Brasil como um país continental com pretensões ou subimperialistas ou expansionistas. $\mathrm{Na}$ verdade, desmanchar essa identidade e/ou capital social negativo na esfera regional não tem sido fácil porque, tomando emprestado o argumento de Oliveiros Ferreira, o temor conspirativo sobre as intenções imperialistas brasileiras arraigou-se muito fortemente nos ministérios de relações exteriores de países vizinhos:"12 "num ponto, forçoso é reconhecer que a política externa de ontem e de hoje tem alguma coisa em comum: o temor de que a América espanhola, nossos vizinhos, considerem que as ações do Itamarati tenham como objetivo afirmar a hegemonia do país no continente" (Ferreira, 2001, pp. 39-40).

O segundo caso significativo que estudaremos é o das relações entre Brasil e Argentina, que também mostra como é possível construir capital social positivo mesmo entre atores estatais historicamente rivais. Tal caso é significativo por várias razões. Como sustentam alguns comentadores, ambos os países mantêm a mais velha rivalidade na América do Sul (Burr, 1955; Mello, 1996), que percorreu o século XIX e se alastrou por todo o sécu- 
lo XX, atingindo o clímax nos governos militares da década de 1960 e 1970. O Brasil e a Argentina disputam influência regional desde sua consolidação como Estados autônomos. A linguagem da balança de poder prevaleceu em disputas sobre territórios de 1825 até 1828 e na disputa pela influência sobre o nascente Estado do Uruguai de 1840 a 1950. O Brasil ajudara na derrocada do ditador argentino Rosas em 1952 e, durante os anos do Barão do Rio Branco no comando do Ministério de Relações Exteriores no Brasil, houve vários momentos de tensão por causa do aumento do arsenal de armas adquiridas por ambos os países. As percepções e as rivalidades foram alimentadas ainda mais durante a Guerra do Chaco (1932-1935) pelas desconfianças brasileiras sobre o papel argentino nesse conflito. Ainda, durante os anos dos governos militares as desconfianças em torno das intenções geopolíticas do Brasil em relação à Argentina chegaram ao paroxismo com o projeto da construção da Usina do Itaipu no final dos anos de $1980 .{ }^{13} \mathrm{O}$ resultado foi a construção de acervos de imagens fortemente negativas entre ambos os países, nos quais se embutem plenas desconfianças sobre as intenções geopolíticas recíprocas.

Apesar das imagens negativas e das desconfianças sobre as intenções regionais brasileiras, quando se observam os campos em que tem existido mais convergência nos últimos vinte anos, é surpreendente apontar que, no início do novo milênio, a maior cooperação entre esses países residem em matérias como desarmamento nuclear e cooperação militar. O caso das relações entre o Brasil e a Argentina sobre as políticas nucleares questionam a assertiva neo-realista de que os Estados não renunciam nunca às capacidades militares ofensivas (Mearsheimer, 2001). Vale lembrar "que a política nuclear de cada país tinha por inspiração a consolidação do poder de cada um e o conseqüente aumento de sua segurança" (Vargas, 1997, p. 45). Como foi possível transformar a linguagem e o histórico de relações que tanto frisaram o poder regional militar no sentido de gerar capital social e confiança entre dois países no que diz respeito a temas tão sensíveis e perpassados historicamente pela construção de identidades negativas e pressupostos de intenções geopolíticas?

Como argumento inicial pode-se sustentar que a existência de imagens externas negativas entre os dois parceiros regionais nem sempre inviabilizou pontos de cooperação; além disso, um mínimo histórico de confiança foi emergindo, tendo como ponto de partida a fase final dos governos militares. Em 1979, Brasil, Argentina e Paraguai assinaram um acordo que finalizou mais de trinta anos de disputa sobre a construção da usina de Itaipu. Antes, em 1978, a Argentina e o Brasil tinham dado mostras de cooperação militar ao disporem suas armadas à realização de exercícios conjuntos numa operação conhecida pelo nome de "Fraterno". Dando seqüência ao jogo cooperativo, em maio de 1980, o general Figueiredo visitou a Argentina, sendo o primeiro presidente a fazê-lo desde 1935. Nesse encontro assinaram acordos sobre produção conjunta de armamentos, além de cooperação e transferência de materiais nucleares. Em agosto desse mesmo ano, o presidente militar argentino Jorge Videla retornou o gesto diplomático de Figueiredo ao visitar Brasília. Nessa ocasião, sete acordos e protocolos nucleares foram assinados. A cooperação foi ampliada em 1981, com a assinatura de acordos adicionais entre a agência brasileira (Nuclebrás) e a agência argentina nuclear (Narc). Outro passo significativo de aproximação deu-se certamente durante a Guerra das Malvinas, quando o Brasil apoiou as reivindicações argentinas, inclusive fornecendo aviões durante o desenvolvimento do conflito bélico entre a Argentina e a Inglaterra.

Essa primeira fase de aproximação foi importante porque permitiu aos decisions makers perceberem qual era o limite do conflito entre ambos os países e que a concorrência regional na Bacia do Prata, embora historicamente legítima, era compatível com a cooperação em temas sensíveis como segurança e desenvolvimento de armamento nuclear. De sua parte, o governo brasileiro percebeu que as imagens geradas por sua intelligentzia geopolítica nos anos do regime militar tinham sido contraproducentes, pois geravam temores e desconfianças com seu principal concorrente sul-americano, e que era necessário, portanto, desconstruir tal imaginário: "Falar da emergência do Brasil como uma grande potência e da geopolítica de Golbery havia servido para aumentar os temores hispano-americanos" (Hurrel, 1998, p. 237).

Nos anos da redemocratização, com os governos de Alfonsin e Sarney, as interações cooperativas 
aumentaram. Ambos os presidentes assinaram em novembro de 1985 acordos sobre cooperação nuclear e abriram o processo de negociação de integração econômica (que, entre 1986 e 1989, incluiu 24 protocolos sob o Programa de Cooperação e Integração Econômica - Pice), seguido pelo Programa de Integração e Cooperação e o Tratado de Cooperação e Desenvolvimento. No marco desses acordos, os dois governos decidiram criar grupos de trabalho envolvendo burocracias nucleares. Dos 24 protocolos assinados no Pice, os de número 11 e 19 tratavam do intercâmbio de informação no caso de acidentes nucleares e do desenvolvimento de pesquisa conjunta, assim como previam visitas técnicas em ambos os países. Outro passo que mostrou um aumento significativo de estratégias cooperativas foi a transformação, em 1988, dos grupo de trabalhos num Comitê Permanente de Assuntos Nucleares.

Dessa forma, as condições políticas e técnicas estavam amadurecidas para consolidar a reciprocidade específica positiva, no sentido empregado por Axelrod (1984). Significativo nessa direção foram as visitas dos presidentes Sarney e Alfonsin aos locais onde se desenvolviam os respectivos programas nucleares no Brasil e na Argentina. "Muito mais enfaticamente, a confiança foi atingida pelas visitas de Sarney [às instalações nucleares] facilitadas pela Argentina em 1987 e 1988 e pela visita de Alfonsin a até então oficialmente desconhecidas [instalações nucleares brasileiras] em Aramar" (Hurrel, 1998, p. 241).

Todavia, é necessário atentar para algumas divergências diplomáticas que poderiam eventualmente impor limitações importantes ao jogo cooperativo seqüencial entre Brasil e Argentina e que mostram bem a dinâmica diplomática de conflito e cooperação em política externa. O discurso tanto da diplomacia presidencial como dos chanceleres do Itamarati tem insistido, desde o governo Sarney (com Abreu Sodré) até o governo Lula (com Celso Amorim), sobre a necessidade de estabelecer uma aliança estratégica com a Argentina, visando ao duplo objetivo explícito de conciliar os objetivos econômicos da integração à procura da estabilidade democrática nos países do Mercosul e da região sul-americana como um todo. Certamente um dos objetivos latentes da política externa brasileira consiste em atenuar, via cooperação regional, as desconfianças argentinas em relação ao
Brasil. Nessa direção cooperativa os porta-vozes mais graduados do Itamarati construíram contemporaneamente o discurso reiterativo segundo $\mathrm{O}$ qual "a parceria estratégica entre Brasil e Argentina é a pedra angular da política para a América do Sul" (Amorim, 2004).

Porém, nos governos do ex-presidente Carlos Menem da Argentina (1989-1999), houve uma evidente assimetria de perspectivas sobre o lugar que cada país ocupava em seus projetos de política externa. Vale lembrar que nesses dez anos de governo, Menem optou pelo chamado "realismo periférico", que apesar de coincidir com os objetivos econômicos de integração no Mercosul adotava um alinhamento político sem restrições com os Estados Unidos. Como notam Russel e Tokliatan, comentando a política externa do governo:

O lugar reservado ao Brasil nesse paradigma [realismo periférico], que se derivava logicamente de suas premissas, foi o de um simples "sócio" econômico, e não de um "aliado estratégico". Assim, aos importantes avanços produzidos no plano doméstico, que aumentaram a interdependência entre os dois países, não correspondeu um aumento das convergências no campo da política externa (2003, p. 89).

Deve-se atentar, porém, que o capital social e a geração de identidades positivas não têm um significado cristalizado. Como reconhece um dos formuladores da política externa brasileira nos anos de 1990, o ex-ministro Celso Lafer (2003, p. 118) "a confiança como capital social pode ser um bem renovável ou não" entre países. Esses tipos de capital social podem ser construídos tanto positiva como negativamente, sendo resultados de um processo de interação seqüencial histórica, em que não é incomum a manutenção entre vizinhos territoriais de acervos imagéticos no âmbito do poder. Nesses casos, as identidades negativas formadas no passado são fatores que limitam e criam importantes constrangimentos à cooperação $\mathrm{O}$ posicionamento argentino nos governos Menem é uma outra forma de constatar que identidades em comum podem certamente levar ao surgimento de comunidades de segurança, contudo a profundidade de identidades históricas divergentes (ou negativas) pode se transformar em obstáculos 
relevantes à cooperação, já que vez por outra são recuperados de seus acervos e mobilizados como recursos de política externa.

Todavia, em que pesem as diferenças nas políticas externas do Brasil e da Argentina durante a era Menem, a idéia de integração regional, com pressupostos democráticos, pode ter sido um poderoso ponto focal para objetivos cooperativos em comum e que permitiu a continuidade e o aprofundamento de empreendimentos cooperativos em áreas sensíveis como segurança e desarmamento. Assim, durante o governo Collor (19901991), esses dois países assinaram, em 1990, a Declaração de Guadalajara, ou Declaração sobre Uso Exclusivamente Pacífico de Energia Nuclear. Essa declaração estabeleceu as bases para a criação da Agência Brasileira-Argentina de Contabilidade e Controle (ABACC). Os dois países avançariam um pouco mais nos compromissos de não proliferação ao assinarem um acordo mais amplo, em dezembro de 1991, o Acordo Quadripartite, entre Brasil, Argentina e a Agência Internacional de Energia Atômica (AIEA) e a ABACC, para a criação de um sistema de monitoramento e salvaguarda nucleares. Juntamente com os esforços de institucionalização do Mercosul pelo Tratado de Assunção de 1991, ainda durante o Collor o Brasil deu um passo importante para esse incremento de confiança quando encerrou suas pretensões de desenvolver armas nucleares, simbolizando essa opção estratégica na clausura do campo de testes da Serra do Cachimbo. Esses acordos firmaram as bases para a completa implementação do Tratado de Tlatelolco, de controle de armas nucleares no continente americano, assim como para o Acordo de Mendoça de setembro de 1991, do qual participou também o Chile, incluindo o controle de armas químicas e biológicas.

Ainda na década de 1990, aprofundaram-se as ações em matéria de segurança e desarmamento, aumentando os níveis de confiança entre Brasil e Argentina, além de sinalizar uma diminuição das suspeitas que, em matéria de geopolítica, haviam alimentado ambos os países durante o regime militar. Em meados dessa década, o Brasil deslocou contingentes completos de tropas da fronteira sul em direção à fronteira norte na Amazônia num claro sinal de que para as elites militares e políticas brasileiras a ameaça represen- tava outro lugar que não a fronteira sul com a Argentina. Nesse aspecto, a Argentina fez um movimento seqüencial de reciprocidade em relação ao Brasil, abandonando a concepção geopolítica de "fronteiras vazias", pela qual políticas de povoamento, de valorização econômica e de construção de infra-estrutura para transporte rodoviário foram descuidadas nas fronteiras com o Brasil, como parte dos temores à geopolítica de expansão brasileira. Hoje, tal política foi revista pela Argentina em conseqüência do processo de integração física estimulada pelo Mercosul.

Acentuando as dinâmicas cooperativas, que tiveram como marco os tratados do Mercosul, implementaram-se as chamadas Medidas de Incremento de Confiança (MIC). Tais medidas englobam simpósios entre os Estados maiores das forças armadas de ambos os países, os exercícios conjuntos entre as armadas dos países do Mercosul, a implementação do Programa de Cooperação e Integração Aeronáutica Argentino-Brasileiro e o Programa de Co-Desenvolvimento do avião CBA-123 entre a empresa aérea brasileira Embraer e a argentina Fama (Giaccone, 1994). A assinatura, em abril de 1996, de um acordo mais amplo sobre cooperação nuclear e pesquisa espacial, assim como a assinatura do Tratado de Não Proliferação Nuclear (TNP) pelo Brasil em 1988 (a Argentina já havia assinado esse tratado em 1995) completam a escalada cooperativa em termos de segurança e controle de armamentos.

Como essa projeção positiva poderia ser explicada a partir de uma perspectiva de capital social? A nosso ver, três fatores são cruciais a esse respeito: 1) o papel das idéias compartilhadas e do auto-interesse; 2) o histórico de reciprocidade específica positiva; e, 3) a criação de normas de transparência e monitoramento, que geraram um sistema de princípios de autogovernança e confiança, institucionalizados em mecanismos de confidence buiding.

O primeiro fator sugere o impacto da visão compartilhada da democracia como valor global entre a Argentina e o Brasil. Nesse nível sistêmi$\mathrm{co}$, as visões brasileira e argentina eram consistentes com a de suas elites governantes. Como transparece o discurso diplomático de um de seus formuladores, essas coincidências são plenamente coerentes com "os valores que se difundem e se 
universalizam no plano internacional" (Cardoso, 2000, p. 60) e que visam ao estabelecimento de padrões de cultura cívica transnacional no sentido afirmado por Ikenberry (2002) para o caso dos Estados Unidos. ${ }^{14} \mathrm{O}$ impacto da idéia de democracia sobre a conduta da política externa e sua capacidade de veiculá-la como recurso político para atingir metas como segurança e desarmamento podem ser compreendidos não só pelo fato de que crenças fornecem guias para os Estados "sobre como atingir seus objetivos", mas também por que, de acordo com Waltz (2000, pp. 106-108), tanto indivíduos como estadistas tendem a selecionar idéias e comportamentos que, socializados internacionalmente, se mostram bem-sucedidos. O exemplo do sucesso de países da Europa Ocidental, enfatizando a interdependência entre democracia e bem-estar social, a regulação dos nacionalismos e os problemas de segurança regional, talvez tenha animado as elites brasileiras e argentinas, desde os governos Sarney e Alfonsin, respectivamente, com o objetivo de que, dada a condição de país em desenvolvimento, a eficácia de ações individuais com tendência a procurar soluções para o problema da segurança dependa de uma assunção do núcleo do discurso democrático global na forma de "liberalismo qualificado". Está claro para as elites brasileiras que formulam a política externa para a América do Sul que a identidade negativa do "subimperialismo brasileiro", construída de longa data, mas acentuada nos anos do regime autoritário pós-64, só pode ser desconstruída seguindo-se um curso de ação que privilegie a atenuação dos acervos imagéticos do poder, substituindo-os por um nacionalismo cívico no sentido mencionado por Ikenberry (2002). Isto é, o enraizamento em ideais democráticos e em regras de direito compartilhadas fornece uma via potencial para a liderança branda em âmbitos regionais por ser menos propenso às políticas de poder.

A combinação de idéias e do auto-interesse em torno de outros objetivos da política externa é importante também para explicar o surgimento de confiança entre a Argentina e o Brasil. Pode-se concordar com a afirmação de que "o interesse próprio dos atores estabelece o fundamento de todos os esforços confiáveis" (Locke, 2001, p. 261), ou com a afirmação de que "escolhas de idéias específicas podem simplesmente refletir os interesses dos atores" (Goldstein e Keohane, 1993 , p. 11). Mas quando combinado com idéias, o auto-interesse pode sustentar metas legítimas em política externa. No caso brasileiro, além de matizar entre seus vizinhos sul-americanos as preocupações com os hipotéticos planos expansionistas, o auto-interesse procurava a institucionalização de normas regionais que estabelecessem relações causais da democracia com outras metas de política externa. Sob a liderança brasileira em 2002, a Reunião de Presidentes da América do Sul em Brasília tentava justificar o vínculo causal entre desarmamento, desenvolvimento e democracia.

Reconhecendo que a paz, a democracia e a integração constituem elementos indispensáveis para garantir o desenvolvimento e a segurança na região, os presidentes destacaram a importância da Declaração do Mercosul, Bolívia e Chile como Zona de Paz e livre de armas de destruição em massa. Assinada em Ushuia, em julho de 1998, o Compromisso Andino de Paz, Segurança e Cooperação, contido na Declaração de Galápagos de dezembro de 1998. Nesse espírito, os presidentes acordaram criar uma Zona de Paz Sul-americana ("Comunicado de Brasília”, 2000, p. 126).

Quanto ao histórico de reciprocidade específica positiva, a combinação de idéias e do autointeresse dos atores é importante também para explicar por que o Brasil sempre destacou durante os anos de 1990 a incompatibilidade entre democratização e pesquisa nuclear com fins bélicos:

[...] o raciocínio com o qual [pretendeu-se] justificar a predisposição a aceitar a renúncia à pesquisa e desenvolvimento de foguetes escondia, estou certo, a convicção, embora não se tornasse explícito, de que qualquer esforço maior nesse sentido seria inútil porque a crise fiscal obrigava a cortar investimentos na área militar - além daquela outra convicção de que, como pretendia o chanceler Lampreia, a redemocratização torna inviável qualquer proposta destinada a cuidar do equipamento das Forças Armadas em termos modernos (Ferreira, 2001, p. 27, grifo nosso).

Certamente, pensar no impacto que teve a redemocratização na geração de confiança não é 
incompatível com o reconhecimento da importância dos fatores sistêmicos ou de alguns fatores institucionais domésticos que também pressionaram no sentido de que a aproximação entre o Brasil e a Argentina fosse uma iniciativa regional diplomática necessária. A partir de uma perspectiva neo-realista, os constrangimentos sistêmicos, tais como as pressões externas da Agência Internacional de Energia (AIEA) e dos Estados Unidos, poderiam sugerir que ambos os países estivessem tentando criar uma agenda positiva de cooperação nos anos da Guerra Fria. Ou de um ponto de vista institucional, a decisão de abandonar projetos de construção de armamento nuclear ou desenvolver tecnologia nuclear também poderia ser explicada pelo fato doméstico de que os poderosos ministérios de relações exteriores dos dois países (Itamarati, no Brasil, e San Matin, na Argentina) tinham visões coincidentes sobre a integração sub-regional em bases democráticas e mutuamente favoráveis sobre as políticas de controle de armamentos. Essa visão compartilhada entre ambas as corporações de política externa teria muita influência sobre os grupos técnicos de trabalho que elaboraram os planos de controle e desarmamento na época da redemocratização (Hurrel, 1998). Em contrapartida poderia ser argumentado com razão que os custos financeiros para desenvolver tecnologia nuclear bélica era muito alto e que a escolha foi no sentido de redirecionar esses recursos para outros aspectos funcionais às metas do desenvolvimento.

Porém, sem negar a importância das variáveis sistêmicas, a influência das corporações de política externa e dos custos financeiros envolvidos, também foi importante porque a redemocratização havia gerado condições políticas entre Brasil e Argentina para a institucionalização de normas de cooperação na agenda de desarmamento. Em outras palavras, o auto-interese dos atores não é incompatível com a percepção de interesses em comum. E o processo de redemocratização deflagrou percepções cognitivas entre atores que permitiram a compreensão recíproca de interesses apesar das diferenças na política externa. Um aspecto fundamental foi que o processo de democratização pode ter fornecido para a Argentina e o Brasil uma visão comum de interesses e identidades e, sobretudo, fez com que compreendessem a vulnerabilidade e a fragilida- de do processo de redemocratização e a importância de sua defesa conjunta. Assim, a cooperação bilateral passou a desempenhar um papel de escudo comum contra as ameaças domésticas ao processo de redemocratização. Embora essas ameaças fossem maiores na Argentina - onde o movimento militar dos Caras pintadas tentou quebrar a institucionalidade democrática no final da década de 1980 -, o governo brasileiro percebeu que o amadurecimento da redemocratização no país dependia em muito da consolidação da democracia na vizinha Argentina. "Acreditar na redemocratização foi importante para redefinir os interesses, as dentidades e um senso comum de propósitos" (Hurrel, 1998).

O terceiro fator - autogovernança e confiança - explica-se pelo fato de que foi possível construir confiança e capital social positivo devido à institucionalização de um sistema de normas de autogovernança de confidence building sobre desarmamento e segurança. A criação de confiança advém de um histórico de reciprocidade especifica positiva que paulatinamente foi institucionalizado desde meados dos anos de 1980. Sem esse histórico de reciprocidade positiva teria sido pouco provável a geração de confiança e a institucionalização desta. Em conseqüência, criou-se um bem-sucedido sistema de normas de autogovernança e de monitoramento $^{15}$ ou de mecanismos recíprocos de confidence building entre ambos os países, o que permitiu a estabilidade e a continuidade dos empreendimentos cooperativos. As confidence building measures objetivam criar transparência, mecanismos de monitoramento nos procedimentos e nas operações militares, diminuir as assimetrias de informações entre os Estados membros de um regime de normas no tratamento de problemas de segurança e desarmamento. A institucionalização do histórico de reciprocidade e do jogo seqüencial de cooperação incluiu, além das ações já referidas durante os anos de 1990, os intercâmbios permanentes entre os staffs dos Estados maiores militares dos dois países e a continuidade dos grupos de trabalho binacionais em matéria nuclear. Também essas de normas de confidence bulding abrangeram a institucionalização dos canais de comunicação entre os dois presidentes, os altos funcionários (seguindo o caminho europeu do segundo pósGuerra Fria), consultas sobre a participação em 
peacekeeping e o estabelecimento da cooperação na tríplice fronteira (Argentina-Brasil-Paraguai) para tratar aspectos de narcotráfico, contrabando e terrorismo. Dessa maneira, Brasil e Argentina criaram condições institucionais de autogovernança com a construção de um framework de normas de confiança em matéria de segurança e desarmamento. Tais condições permitiram o estabelecimento de: 1) medidas de coordenação e monitoramento de política nuclear; 2) "novos hábitos de comunicação", incentivos para a mudanças de atitude e de percepções e novos padrões de interação estratégica"; e, 3) consenso de interesses a ser atingido via cooperação, mesmo se tratando de aspectos sensíveis à segurança nacional, como o projeto de energia nuclear.

Analiticamente é possível afirmar que a partir desses desenvolvimentos históricos a Argentina e o Brasil estabeleceram as bases para a formação de uma comunidade minimalista ou fraca de segurança (loosely coupled security community), no sentido descrito por alguns teóricos quando afirmam que as "sociedades mantêm expectativas confiáveis de mudança pacífica" (Adler e Barnet, 1998a, p. 30). Ambos os atores compartem minimamente valores, identidades e significados comuns, praticam a reciprocidade específica, característica esta que implica em certo grau de interesse de longo prazo, assim como na geração de um senso de responsabilidade e obrigação em comum, e, ainda, alimentam expectativas de solução de conflitos que descartam os recursos de poder baseados na força (power-based).

No entanto, se do ponto de vista conceitual o procedimento explicativo da política externa brasileira nem sempre é o mais esclarecedor em relação a essas temáticas, ${ }^{16}$ deve-se reconhecer que a escolha do "mapa do caminho" democrático abre portas para resolver o dilema de como continuar mantendo suas aspirações de liderança regional sem que isso seja percebido pelos vizinhos sul-americanos como a continuidade de um objetivo expansionista. Como reconhecem os setores ligados à corporação diplomática, o pathway democrático significa um efetivo soft power de credibilidade para a política externa (cf. Lafer, 2003), o qual atenuaria suspeitas de que no futuro o governo poderia optar pelo recurso do tipo based-power. Não estamos sugerindo que a democracia e as declara- ções pacifistas doutrinárias sejam a única dimensão explicativa das escolhas em política externa, mas que elas são importantes no contexto do pósGuerra Fria em termos de procedimentos explicativos da política externa, sobretudo para os atores que procuram justificar tal ação ou escolha para o público doméstico. Esses procedimentos explicativos transformam-se em atitudes simbólicas que visam a legitimar e viabilizar ideologicamente a globalidade dos interesses nacionais, como nos lembra Fonseca (1998).

Entre essas atitudes simbólicas, sem dúvida não se pode negar a ponte que liga credibilidade, confiança e imagem externa à aderência a regimes de não proliferação de armas. Essa sentença é mais verdadeira para o caso de temas sensíveis, em que normas de segurança internacional, baseadas em confidence building, requerem transparência e monitoramento na execução de regimes que regulamentam a matéria, requisitos esses para os quais as democracias estão, em princípio, mais predispostas a aceitar e em melhores condições de atender. Em síntese, em que pesem tanto as assimetrias de políticas externas como a permanência de imagens negativas construídas no passado, a democratização levou a uma variação significativa do conteúdo dessas duas variáveis, permitindo a construção de um capital social positivo entre a Argentina e o Brasil. Isto quer dizer que as imagens negativas e as desconfianças se amorteceram e que as divergências hoje incidem sobre quais seriam os melhores meios econômicos e quais alianças políticas seriam mais privilegiadas para a inserção do país no mundo globalizado.

Na verdade, o pathway sugerido pela democracia como recurso de ação da política externa na geração de capital social positivo pôde ajudar a resolver dois dilemas de ação coletiva vivenciados pela política externa brasileira. Ao assumir que os sistemas sul-americanos podem se organizar de maneiras variadas sob o que denominamos "liberalismo político qualificado", ${ }^{17}$ o Brasil construiu a base para promover a estabilidade democrática como instrumento útil de cooperação regional sulamericana sem ser percebido por seus vizinhos como um país exportador de valores democráticos homogeneizadores que não levam em conta as especificidades nacionais. De outra parte, o "liberalismo político qualificado" assegurou uma coe- 
rência ideológica com os valores políticos ocidentais e certa margem de autonomia ante os Estados Unidos, ao mesmo tempo em que sinalizava para os vizinhos sul-americanos a mesma possibilidade de escolha sem que houvesse uma idéia rígida de democracia globalizada, como sugerem os teóricos do "fim das ideologias". Em segundo lugar, possibilitou esclarecer, para as elites brasileiras, a natureza política das condições político-institucionais nas quais é possível procurar interesses políticos e econômicos regionais de maneira mais eficiente, e a um só tempo ser ideologicamente coerente com a normatividade liberal global, isto é, sem grandes lacunas entre a economia liberal e a natureza do sistema político doméstico. ${ }^{18}$

\section{Considerações finais}

O que têm em comum os casos estudados? Compartem a importância do reconhecimento de que o auto-interesse é compatível com a satisfação recíproca, o que sugere que a construção de capital social entre Estados é mais do que um jogo racionalista de soma-zero, permitindo, por sua vez, a desconstrução de imagens negativas. Outro ponto comum constitui um aspecto significativo ignorado pelas teorias de relações internacionais meanstream: a geração de confiança entre atores estatais é possível a despeito da natureza anárquica do sistema internacional. E, finalmente, os casos analisados mostram que há duas condições para gerar a confiança: 1) histórico de reciprocidade positiva; e 2) compartilhamento de visões de mundo normativas cooperativas, pois, caso contrário, na hipótese da partilha de visões negativas, a geração de confiança seria uma meta muito difícil de ser atingida. Entre as visões normativas compartilhadas nos dois casos, a possibilidade da agenda democrática como recurso de política externa configurou-se como a principal alternativa. Nesse ponto, o discurso democrático da política externa brasileira tem sido o mais importante recurso para a transformação das desconfianças em confiança dos países sul-americanos em relação ao Brasil.

É viável pensar a agenda democrática em termos de geração de capital social positivo? A afirmação de vantagens na implementação de uma agenda democrática na América do Sul não significa que devamos ter como pressuposto a existência de condições para a sua geração. Esse parece ser o maior ponto de vulnerabilidade na política externa brasileira, que tem por base a consolidação institucional democrática na América do Sul. A fragilidade da implementação de uma agenda democrática no continente, visando a fortalecer o projeto de integração regional e a confiança mútua, não decorre tanto de sua capacidade de ação e iniciativa política - esta, existe de fato, como mostraram as atuações da política externa desde o golpe de Fujimori no Peru, em 1992, até as crises políticas na Bolívia em 2003 e 2005. A principal limitação parece recair sobre as condições políticas em que se desenvolvem as democracias regionais ou democracias delegativas, como tem sido chamada por alguns autores. ${ }^{19} \mathrm{O}$ baixo grau da continuidade e da institucionalização das chamadas regras do jogo em vários países da região, em especial no conjunto dos países da Comunidade Andina, impossibilita um mínimo de congruência entre a racionalidade formal (exprimida juridicamente em constituições, cláusulas ou decretos) e a prática efetiva da democracia.

Também as identidades negativas do passado são um grande obstáculo à implementação de uma agenda democrática para a América do Sul. Em que pesem os esforços brasileiros por melhorar sua imagem, e mesmo sustentando a necessidade do princípio de não intervenção, exemplos mais recentes, como o caso boliviano, ${ }^{20}$ mostram que as elites desses países continuam muito sensíveis a discursos e imagens do passado sobre as intenções expansionistas do Brasil. Em outras palavras, o discurso da democratização da região e da estabilidade das regras constitucionais veiculado pela política externa brasileira ainda não resolve satisfatoriamente o problema das intenções reais da política externa brasileira nas percepções de alguns de seus vizinhos.

Também é verdade que não é suficiente que o caminho democrático esteja institucionalizado em cada país. Um importante requisito é que as metas prescritas devem contar com "a existência de um conjunto de crenças compartilhadas" (Goldstein e Keohane, 1993) sobre as qualidades sem par do mapa que serve de guia às ações. ${ }^{21}$ Essas crenças podem estar emergindo, porém temos elementos empíricos para sustentar 
tal hipótese? Em primeiro lugar, as relações bilaterais cooperativas com a Venezuela, que datam de bem antes da chegada de Chávez ao poder, mostram que é possível construir uma relação de confiança se as relações cooperativas tiverem continuidade em ações concretas. Em segundo, a ação coletiva sugere um mínimo de esforço de coordenação. Nesse sentido, no que diz respeito ao Brasil, se as cúpulas sugerem algum tipo de ação coletiva substantiva, a Reunião de Presidentes da América do Sul de setembro de 2000, realizada em Brasília, destacou a democracia representativa como "fundamento da legitimidade dos sistemas políticos" e uma interconexão entre "paz, estabilidade e desenvolvimento da região" ("Comunicado de Brasília", 2000, p. 128).

Embora possamos reconhecer que tais parâmetros empíricos sejam ainda uma evidência fraca para responder ao problema da ação coletiva baseada em idéias compartilhadas, existe pelo menos um elemento importante a ser destacado: "a teoria das relações internacionais sugere ser necessário um acordo básico entre atores para levar uma política à frente ou existência de um ator com suficiente capacidade de alavancagem" (Vigevani, 2000, p. 3). A maior capacidade do Brasil em termos regionais não é só um dado geográfico, é também um dado político. Daí sua maior capacidade de alavancar visões de mundo que, de outra maneira, seriam percebidas pelos atores regionais como um bem público regional em construção, capaz de gerar confiança entre Estados na base de expectativas recíprocas sobre as vantagens da democratização regional como elemento-chave do relacionamento diplomático.

No entanto, deve-se ter cautela quanto a hipóteses que tratem a precondição democrática como o objetivo final da política externa brasileira na região sul-americana. Talvez a melhor síntese dessa cautela, e que expressa o frágil equilíbrio entre idéias e interesses, esteja resumida no discurso diplomático contemporâneo de "não intervenção, mas sem indiferença", esboçado por formuladores contemporâneos de política externa (Amorim, 2004), asserção essa que baliza bem os limites possíveis de uma ação baseada em princípios.

Todavia, a metodologia explicativa da política externa em bases normativas cumpre um destacado papel para justificar a democracia como recurso de poder soft na América do Sul, uma vez que a região é definida como um dos elementos formadores da identidade externa brasileira. Certamente, a tradição normativa, independentemente de ser o certificado de "grociano" o mais adequado para expressar o conteúdo doutrinário pelo qual se baliza a ação externa, tem sido aproveitada bastante bem para desenvolver esse papel. O apelo à tradição normativa ou doutrinária grociana cumpre razoavelmente a função de satisfazer o público interno, caso a opinião pública não compreenda qual é o lugar do interesse nacional na ação externa em curso, como é comum acontecer no exercício de agendas externas baseadas em princípios. Também as razões explicitadas pela matriz normativa satisfazem um público externo, que aceita com menos resistência a idéia da exportação da estabilidade democrática como um bem público regional, em contraste com a do imperialismo brasileiro, cuja imagem esteve tão enraizada nos vizinhos sul-americanos durante quase todo o regime militar.

Uma vantagem considerável dos formuladores da política externa brasileira para os objetivos da consolidação da agenda democrática é a bemsucedida transição democrática no país, que teve seu ponto alto na passagem do governo de Fernando Henrique Cardoso para o de Luis Inácio Lula da Silva. Essa exitosa transição pode ser operacionalizada como recurso de ação externa, isto é, como modelo a ser seguido por alguns países da região e que certamente aumenta a potencialidade de credibilidade sobre suas intenções não predatórias, mas sim benéficas da política externa brasileira.

\section{BIBLIOGRAFIA}

ADLER, Emanuel. (1992), "The emergence of cooperation: national epistemic and the international evolution of the idea of nuclear arms controls". International Organizations, 46 (Issue I): 101-145.

ADLER, Emanuel \& BARNET, Michael. (1998a), "Security communities in theoretical perspective", in E. Adler e M. Barnett (eds.), Security communities, Cambridge, Cambridge University Press. 
(1998b), "A framework for the study of security communities", in E. Adler e M. Barnett (eds.), Security communities, Cambridge, Cambridge University Press.

ALBUQuerque, José A. G. (1997), Percepções das elites e da sociedade sobre o Mercosul $e$ as relações externas brasileiras. São Paulo, Nupri/USP.

ALMOND, Gabriel \& VERBA, S. (1989), The civic culture: political atitudes and democracy in five nations. Nova York, Sage.

AMORIM, Celso Luiz Nunes. (1994a), "Uma diplomacia voltada para o desenvolvimento e a democracia", in Gelson Fonseca Jr. e Sérgio Henrique Nabuco Castro (orgs.), Temas de politica externa brasileira II, São Paulo, Ipri/Paz e Terra, vol. 1.

(1994b), "Perspectivas do Brasil". Política Externa, 2 (3): 132-142, dez.-fev.

(2004), "Aula magna proferida na UFRJ". Rio de Janeiro, 12 mar. Disponível no site http://www.mre.gov.br/index.htm.

AXELROD, Robert. (1884), The evolution of cooperation. Nova York, Basic.

BALWIN, David (ed.). (1993), Neorealism and neoliberalism: the contemporary debate. Nova York, Columbia University Press.

BAQUERO, Marcelo. (2003), "Construindo uma outra sociedade: o capital social na estruturação da política participativa no Brasil". Revista de Sociologia e Politica, 2: 83-108, nov.

BOSCHI, Renato Raul. (1999), "Descentralização, clientelismo e capital social na governança urbana: comparando Belo Horizonte e Salvador". Dados - Revista de Ciências Sociais, 42 (4): 655-690.

BURR, Robert N. (1955), "The balance power in nineteenth-century South America: an exploratory essay". Hispan American Historical Review, 35 (1): 90-100.

CAMARA LIMA PESSÔA, Irene de. (1998), Em nome da democracia: a OEA e a crise haitiana - 1991-1994. Brasília, Fundação Alexandre Gusmão.
CARDOSO, Fernando Henrique. (1993), "Política externa: fatos e perspectivas". Política Externa, 2 (1): 3-10, jul.-ago.

(2000), "Palestra do senhor presidente da República, Fernando Henrique Cardoso, no Centro Brasileiro de Relações Internacionais (Cebri)". Rio de Janeiro, 14, set. Disponível em no site http:// www.ftp.unb.br/pub/UNB/ipr/rel/discpr/ 2000/2929.pd.

CARTA CAPITAL. (2003), "Via BNDES, e suas petroleiras, Lula e Chávez aprofundam as relações políticas e comerciais entre Brasil e Venezuela" Carta Capital, IX (238): 30-32.

CASTRO, Terezinha de. (1976), Rumo à Antártica. São Paulo, Livraria Freitas Bastos.

CERVO, Amado Luiz. (2001), "A Venezuela e os seus vizinhos”. Revista Cena Internacional, 1: 7-10.

CISNEROS, Imelda et al. (1998), El desarrollo del comercio y las inversiones entre Brasil y Venezuela. Brasília, Fundação Alexandre Gusmão.

"COMUNICADO de Brasília". (2000), "Reunião de presidentes da América do Sul". Política Externa, 9 (2): 125-135, set.-nov.

CORREA ROCHA, Henrique. (1965), O Brasil e as Guianas. Catanduva, Ibel.

COUTO e SILVA, Golberi do. (1967), Geopolitica do Brasil. Rio de Janeiro, Livraria José Olympio.

DEUTSCH, Karl W. et al. (1957), Political community in North Atlantic area. Princenton, Princenton University Press.

FARER, Tom. (1996), "Colectively defending democracy in the western hemisphere: introduction and overview", in Tom Farer (ed.), Beyond sovereignty: collectively defending democracy in the Americas, Baltimore/Londres, The Johns Hopkings University Press.

FERREIRA, Oliveiros S. (2001), A crise da política externa: autonomia ou subordinação. São Paulo, Revan. 
FONSECA, Gelson Junior. (1998), A legitimidade e outras questôes de política internacional. Rio de Janeiro, Paz e Terra.

FUKUYAMA, Francis. (1995), Trust: the social virtues and the creation of prosperity. Nova York, The Free Press.

GIACCONE, Claudia A. (1994), "Cooperacion estrategico miltar en el Mercosur", in Conselho Brasileiro de Relações Internacionais (org.), Mercosur: desafios a vencer, São Paulo, Conselho Brasileiro de Relações Internacionais.

GIBBSONS, Robert. (2001), "Trust in social structures: Hobbes and couse meet repeated game", in Karen Cook (ed.), Trust in society, Nova York, Russel Sage Foundation.

GOLBERG, David. (2001), "Is there a democratic regimes evolving in the Western hemisphere? Some lessons from he 1990's". Prepared for delivery at the 2001 meeting of the Latin American Studies Association, Washington (mimeo.).

GOLDSTEIN, Judith \& KEOHANE, Robert (eds.). (1993), Ideas and foreign policy: beliefs, institutions, and politics changes. Ithaca/ Londres, Cornell University Press.

GRIECO, Joseph. (1993), "Understanding the problem of international cooperation: the limits of neoliberal institutionalism and the future of realist theory", in David Balwin (ed.), Neorealism and neoliberalism: the contemporary debate, Nova York, Columbia University Press.

HALPERN, Nina. (1993), "Criating socialist economies: stalinist political economy and the impact of ideas", in Judith Goldstein e Robert Keohane (eds.), Ideas and foreign policy: beliefs, institutions, and politics changes, Ithaca/Londres, Cornell University Press.

HARDIN, Russel. (2001), "Conceptions and explanations of trust", in Karen Cook (ed.), Trust in society, Nova York, Russel Sage Foundation.

HASS, Peter. (1992). "Introduction: epistemic com- munities and international policy coordination”. International Organization, 46 (1). Issue I, Knowledge, Power and International Policy Coordination, winter.

HURREL, Andrew. (1998), "An emerging security community in South America?", in E. Adler e M. Barnett (eds.), Security communities, Cambridge, Cambridge University Press.

IKENBERY, G. John. (2002), "American unipolarity: the sources of persistence and decline", in Ikenbery, G. J. Ikenberry (ed.), America unrivaled: the future of the balance power. Ithaca/Londres, Cornell University Press.

KEOHANE, Robert. (1993a), "La reciprocidad en las relaciones internacionales", in Instituciones internacionales $y$ poder estatal, Buenos Aires, Grupo Editor Latinoamericano.

(1993b), "Institutional theory and the realist change after the Cold War", in David Balwin (ed.), Neorealism and neoliberalism: the contemporary debate, Nova York, Columbia University Press.

LAFER, Celso. (2001a), A identidade internacional do Brasil e a politica externa brasileira: passado, presente e futuro. São Paulo, Perspectiva.

(2001b), "Aula ministrada no Instituto Rio Branco pelo senhor ministro das relações exteriores". Disponível no site http://www.mre.gov.br/sei/lafer-aulariobranco.htm.

(2003), "Reflexões sobre uma gestão". Politica Externa, 11 (4): 111-137, mar--maio.

LAFER, Celso \& FONSECA JR., Gelson. (1994), "Questões para a diplomacia no contexto internacional das polaridades indefinidas", in G. Fonseca Jr. e Sérgio Henrique Nabuco Castro (orgs.), Temas de politica externa brasileira II, São Paulo, Ipri/Paz e Terra, vol. 1.

LAMAZIERE, Georges. (2001), "Brasil e América do Sul, uma convergência”. Politica Exter- 
na, 4 (4):42-48, mar. -maio.

LOCKE, Richard. (2001), "Construindo confiança". Econômica, 3 (2): 253-281, set.

MARTINS, Luciano. (1992), “A reformulação da ordem internacional”. Politica Externa, 1 (1): 116-119, jun.

MEARSHEIMER, John J. (2001), The tragedy of great power politics. Nova York/Londres, W.W Norton and Company.

MEIRA MATTOS, C de. (1975), Brasil: geopolítica $e$ destino. Rio de Janeiro, Biblioteca do Exército Editora.

MELLO ALMEIDA, Leonel I. (1996), Argentina e Brasil: a balança de poder no Cone Sul. São Paulo, Annablume.

MENDIBLE, Alejandro. (1995), "Los caminos del encuentro: hacia la integración Venezuela-Brasil". El Universal, 3 jul., p. A-11.

MINISTERIO de Relaciones Exteriores (Caracas). (2005), "Inserción protagónica de Venezuela”. Disponível no site Http://www. mre.gov.ve.

MINISTERIO de Relaciones Exteriores de Venezuela. (2002), "Inserción protagónica de Venezuela”. Disponível no site http://www. mre.gov.ve.

(2005), "Palabras del ministro de Relaciones Exteriores, Luis Alfonso Dávila. Acto de entrega del MRE al nuevo titular. 23 de febrero de 2001". Caracas, Dirección General de Información y Opinión. Disponível no site http://www.mre.gov.ve.

MIYAMOTO, Shiguenoli. (1999), "O estudo das relações internacionais no Brasil: o estado da arte". Revista de Sociologia e Política, 12: 93-98, jun.

NORTH, Douglas. (1990), Institutions, institutional changes and economic perfomance. Cambridge, Cambridge University Press.

NYE, Joseph Jr. (2002), O paradoxo do poder americano. São Paulo, Editora da Unesp.

O’DONNELL, Guilhermo. (1991), "Democracia delegativa". Novos Estudos CEBRAP, 31:
$25-40$.

ORGANIZAÇÃO dos Estados Americanos. (2001), Carta Democrática: documentos e interpretações. Washington, OEA.

PUTNAM, Robert D. (1993), Making democracy: work: civic traditions in modern Italy. Princenton, Princenton University Press.

(1997). Comunidade e democracia: a experiência da Itália moderna. Rio de Janeiro, Fundação Getúlio Vargas.

RAMOS, Danielly Silva. (1995), "Brasil-Venezuela: a nova integração". Revista Brasileira de Politica Internacional, 38: 99-10.

REIS, Bruno Wanderley. (2003), "Capital social e confiança: questões de teoria e método". Revista de Sociologia e Política, 2: 35-49, nov.

RISSE, Thomas. (2002), "U.S power in a liberal security community", in John Ikenberry (ed.), America unrivaled: the future of power the balance power. Ithaca/Londres, Cornell University Press.

ROMERO, Carlos. (2002), "El pasado y el presente de la política exterior de Venezuela", in Marisa Rollòn Ramos (ed.), Venezuela: rupturas y continuidades del sistema politico (1999-2001). Salamanca, Ediciones de la Universidad de Salamanca.

RUGGIE, John Gerard. (1998), Constructing the world polity. Londres/Nova York, Routledge.

RUSSEL, Roberto \& TOKATLIÁN, Juan Gabriel. (2003), "O lugar do Brasil na política externa da Argentina: a visão do outro". Novos Estudos CEBRAP, 65: 71-90, mar.

SANTISO, Carlos. (2002), "Promoção e proteção da democracia na política externa brasileira". Contexto Internacional, 24 (2): 397-431.

SCHMITT, Carl. (1992), O conceito do político. Petrópolis, Vozes.

SILVA, Luiz Inácio Lula da. (2003), "Discurso do senhor presidente da República, Luiz Inácio Lula da Silva, na Sessão de Posse, no Congresso Nacional". Disponível no 
site www.mre.gov.br.

SOARES de LIMA, Maria Regina. (1994), "Ejos analíticos e conflitos de paradigmas en la política exterior brasileña". América Latina/Internacional, 1 (2): 253-281.

(2000), "Instituições democráticas e política exterior". Contexto Internacional, 22 (2): 265-302.

SCHUMPETER, J. A. (1984), Democracia, socialismo e capitalismo. Rio de Janeiro, Zahar.

VARGAS, Everton V. (1997), “Átomos na integração: a aproximação Brasil-Argentina no campo nuclear e a construção do Mercosul". Revista Brasileira de Politica Internacional, 40 (1): 41-74.

VIGEVANI, Tullo. (2000), "Reflexões sobre a reunião presidencial sul-americana". Panorama da Conjuntura Internacional, ano 7 (2): 1-3, out.-nov.

VILLA, Rafael Duarte. (2003), "A questão democrática na agenda da OEA no pós-Guerra Fria”. Revista de Sociologia e Política, 20: 55-68, jun.

(2004). "Política externa na administração Hugo Chávez”. Política Externa, 13 (1): 99-119, jun.-ago.

VISENTINI FAGUNDES, Paulo G. (1995), "Venezuela e Brasil na política internacional". Samuel Guimarães Pinheiro (org.), Brasil e Venezuela: esperanças e determinação na virada do século. Brasília, Ipri/Fundação Alexandre Gusmão.

WALTZ, Kennetz. (2002), Teoria das relações internacionais. Lisboa, Gradiva.

WENDT, Alex. (1992), "Anarchy is what states make of it". International Security, 46: 391-285.

(1995), "Construing international politics”. International Security, 20: 71-81.

\section{Notas}

1 A reciprocidade específica é definida por oposição à reciprocidade difusa. A característica desta é o fato de uma das partes ter a possibilidade de não receber recompensas diretas, mas usufruir os "resultados gerais satisfatórios do grupo do qual faz parte [...] [, ao passo que] um modelo de reciprocidade difusa só pode se manter por meio de um amplo sentido de obrigação" (Keohane, 1993, p. 209).

2 Goldstein e Keohane esclarecem que "quando nos referimos a idéias neste volume falamos de crenças - compartilhadas por um grande número de pessoas - acerca da natureza de seus mundos e que têm implicações para a ação humana. Tais crenças englobam desde princípios morais gerais até acordos sobre uma aplicação específica do conhecimento científico" (1993, p. 7).

3 Lembremos que, nesse contexto, realizou-se no Rio de Janeiro, em abril de 1992, o encontro chamado de "Agenda da Conferência sobre a Nova Ordem Internacional", organizado pelo Instituto Nacional de Altos Estudos-Fórum Nacional e coordenado por Luciano Martins e João Paulo Reis Velloso. O encontro contou com a participação de Helmut Schmitt (ex-primeiro ministro da Alemanha) e de Robert McNamara, ex-secretário de defesa dos Estados Unidos, além de destacados intelectuais do mundo acadêmico das relações internacionais, como Robert Gilpin (Martins, 1992).

4 Uma posição discordante a esse consenso foi a nota oficial do governo venezuelano de Hugo Chávez: "As reservas do presidente Chávez centram-se nos dois parágrafos do texto firmado pelos governantes, ambos por incluir a frase 'democracia representativa' a que o Chefe de Estado opõe-se abertamente, porque a chamada democracia representativa é uma armadilha que levou o povo venezuelano à violência. O Mandatário venezuelano adere ao conceito de democracia participativa, que complementa, reforça e amplia a democracia representativa com base no pluralismo político, no exercício da soberania exercida pelo povo, no caráter alternativo, no regime pluralista de partidos e de organizações políticas, no respeito aos direitos humanos e às liberdades fundamentais" (Ministerio de Relaciones Exteriores [Caracas], "Inserción protagónica de Venezuela", documento disponível no site http:// www.mre.gov.ve, em 30/6/2005). Entretanto, a OEA não somente rechaçou o conceito de democracia participativa como também assumiu plenamente o conceito de democracia representativa.

5 O "Comunicado de Brasília" da reunião de presidentes da América do Sul manifesta esta preocupação ao se dispor a "realizar consultas políticas na 
hipótese de ameaça de ruptura da ordem democrática na América do Sul".

6 Segundo pesquisa do Núcleo de Pesquisas de Relações Internacionais da USP (Nupri), que trata da percepção das elites brasileiras sobre o Mercosul e sobre a política externa brasileira, mais de $57 \%$ das elites acreditam que "a atuação externa do Brasil [especialmente na América do Sul] visa garantir a prosperidade interna" (Albuquerque, 1997).

7 A administração Chávez tem retomado a idéia com o nome de Petrosul.

8 O conceito de "fronteiras de cooperação" é atribuído por Celso Lafer ao embaixador Luiz Felipe de Seixas Correia.

9 Segundo a fonte, até 2002 a Venezuela representava US\$ 1,5 bilhão (ou seja $6 \%$ do comércio venezuelano), muito pouco comparado com a Argentina, com quem mantém um volume de negócios de US\$ 9 bilhões (Carta Capital, 2003, p. 30).

10 Por outro lado, tendo em conta a possibilidade desse interesse, é possível interpretar dessa maneira a intensa atividade diplomática que vem ocorrendo desde de 2001 em relação à China, que incluiu a reciprocidade de visitas de Chávez e Jian Zeming, assim como a assinatura de um "Plano estratégico energético China-Venezuela, 2001-2011 para o fornecimento de energia a esse país e com vistas a incursionar no restante do mercado asiático" (cf. Ministerio de Relaciones Exteriores, 2002).

11 Assim chamada em referência a seu formulador, Rómulo Betancourt, primeiro presidente da era democrática venezuelana, iniciada em 1959.

12 Essa imagem do Brasil é bastante incompatível com o pensamento das elites brasileiras. De acordo com a pesquisa do Núcleo de Estudos em Relações Internacionais da USP (Nupri), 91\% das elites entrevistadas discordaram da afirmação de que o "Brasil pretende exercer hegemonia" na América do Sul. (Albuquerque, 1997).

13 Na visão conspiratória de militares argentinos não era incomum escutar que os brasileiros estavam construindo a usina com propósitos de no futuro usá-la, muito provavelmente, como uma bomba de água (cf. Shiguenoli, 1999).

14 Ver páginas iniciais deste artigo.

15 O conceito de autogovernança e monitoramento é de Locke (2003, p. 261).
16 A nosso ver, Oliveiros Ferreira tem razão quando afirma que "essa [relação entre liderança e hegemonia] possivelmente nem acadêmica seja; diplomaticamente coloca os governos vizinhos em situação embaraçosa, pois devem chamar seus $\mathrm{PhD}$ para lhes explicarem qual é a diferença entre um país considerar-se líder ("alguma liderança") mas não querer que o vejam como pretendendo ser hegemônico. Gramsci talvez sirva como tema de teses acadêmicas, mas não seguramente para cimentar ações diplomáticas" (2001, p. 39).

17 A perspectiva de liberalismo qualificado adotada significa que tanto os valores como a organização institucional de sociedades democráticas não precisam se ajustar rigidamente ao modelo dos Estados Unidos ou da Europa Ocidental. Existem variações possíveis de organização institucional que expressam gradações de funcionamento da democracia liberal em correspondência com as especificidades nacionais ou regionais.

18 De acordo com a pesquisa do Núcleo de Pesquisas em Relações Internacionais da USP (Nupri), o pensamento das elites consultadas é de que a liderança regional é plenamente congruente com a convivência pacífica com seus vizinhos sul-americanos. Se $92,3 \%$ das elites enxergam o Brasil como uma liderança regional, quase o mesmo percentual $(91,6 \%)$ acredita que o país "busca cooperar para uma convivência pacífica" (Albuquerque, 1997).

19 Guillermo O'Donnell denominou "democracia delegativa" aquela que corresponde a um modelo mais realista de democracia: baixa definição e institucionalização das práticas democráticas e pouca transparência no exercício das regras do jogo eleitoral. Outro elemento notável desse arranjo democrático é o mito de que o presidente, uma vez eleito pela maioria, pode agir de qualquer maneira, bastando para isso invocar e relembrar o percentual de votos que recebera. Também fazem parte desse modelo real a ausência de um mecanismo vertical e horizontal (entre os poderes públicos) de accountability e a definição unilateral da agenda por parte do presidente da República e seus principais assessores, sem levar em conta a voz de grupos de interesses e de outros segmentos públicos, como partidos e o Congresso. Além disso, temos as constantes acusações trocadas entre $o$ presidente e o Congresso sobre quem é responsável por determinada crise. O produto da soma desses elementos políticos é uma imensa solidão no poder por parte do presidente da República, o que pode se transformar em vazio de poder, 
resultando em perda de legitimidade quando ainda está por vezes na metade do mandato. "Como institucionalizar uma democracia que faz diretamente o oposto daquilo que foi prometido?" (O’Donnell, 1991).

20 Imagens sobre o subimperialismo brasileiro voltaram a surgir fortemente na Bolívia entre setores nacionalistas como resultante dos amplos e agressivos investimentos em gás e petróleo feitos pela estatal brasileira do petróleo - Petrobrás.

21 Com exceção da Venezuela de Hugo Chávez, o restante dos países sul-americanos, assim como de todos os que integram o sistema interamericano da Organização dos Estados Americanos - OEA, adotam de maneira oficial o conceito de "democracia representativa". 


\section{POLÍTICA EXTERNA \\ BRASILEIRA: CAPITAL SOCIAL E DISCURSO DEMOCRÁTICO NA AMÉRICA DO SUL}

\section{Rafael Duarte Villa}

Palavras-chave: Política externa brasileira; Capital social; Argentina; Venezuela; Auto-interesse.

A idéia de democracia e democratização, com objetivo de gerar capital social positivo e confiança entre o Brasil e seus vizinhos sulamericanos, revelou-se tanto para as elites brasileiras como para os formuladores de política externa um "mapa do caminho" em termos de segurança e integração regional e de política de desarmamento. Assim, sob o impacto de idéias sugeridas por novas visões de mundo, a política externa brasileira transformou um fator de política interna - a organização democrática do sistema político - em condição e recurso de sua política externa sul-americana. O resultado foi uma melhoria na imagem e na credibilidade na política regional sulamericana, ou seja, um incremento na "confiança". Este é o argumento desenvolvido aqui, baseado numa metodologia que aproveita trechos extraídos do discurso diplomático dos próprios formuladores da política externa brasileira contemporânea e nas reconstruções históricas de relações diplomáticas do Brasil com dois países sul-americanos, Venezuela e Argentina, nas décadas de 1980 e 1990.

\section{BRAZILIAN FOREIGN AFFAIRS: SOCIAL CAPITAL AND THE DEMOCRATIC DISCOURSE IN SOUTH AMERICA}

Rafael Duarte Villa

Keywords: Brazilian foreign affairs; Social capital; Argentina; Venezuela; Self-interest.

Brazilian elites as well as foreign policy-makers have long shared a common belief that the ideas of democracy and democratization should serve as some "road map" to foreign policy-making. In areas such as security, regional integration, and disarmament, the goal has been to generate a positive social capital as well as to build trusting relations with Brazilian neighbors in South America. Therefore, under the impact of ideas brought about by new world visions, Brazilian foreign policy has changed a domestic policy feature - the democratic rearrangement of the political system - into a condition and resource for foreign policy-making towards South America. The result has been a fine improvement of Brazilian image and credibility in the regional South American scenario. In other words, there has been a significant increment in "trust" towards Brazil. This argument has been developed based on extracts and transcripts from official diplomatic speeches from Brazilian foreign policy-makers as well as a historical reconstruction of Brazil's diplomatic relations with two South American countries. Our study was based on two cases: BrazilianVenezuelan and Brazilian-Argentine relations in the 80's and the 90's.

\section{POLITIQUE EXTÉRIEURE BRÉSILIENNE: CAPITAL SOCIAL ET DISCOURS DEMOCRATIQUE EN AMÉRIQUE DU SUD}

Rafael Duarte Villa

Mots-clés: Politique extérieure brésilienne; Capital social; Argentine; Venezuela; Intérêt personnel.

Les idées de démocratie et de démocratisation ont longtemps été un consensus parmi les élites brésiliennes et les formulateurs de politique étrangère, qui considèrent ces idées comme une sorte de "trajet" pour la formulation de la politique étrangère brésilienne. Dans les domaines de la sécurité, de l'intégration régionale et du désarmement, le but politique du Brésil a été la création d'un capital social positif et la construction de relations de confiance avec ses voisins en Amérique du Sud. Ainsi, et sous l'impact des idées issues de nouvelles perceptions du monde, la politique étrangère brésilienne a transformé une donné de politique intérieure - la réorganisation démocratique du système politique - en une condition et des ressources pour la formulation de la politique étrangère vers l'Amérique du Sud. Le résultat a été une amélioration significative de l'image et de la crédibilité du Brésil dans le scénario régional sud-américain. Autrement dit, une hausse importante en ce qui concerne le niveau de confiance par rapport au Brésil a eu lieu. Cet argument a été développé à partir d'extraits et de transcriptions du discours diplomatique officiel des formulateurs de politique étrangère brésilienne, ainsi que de la reconstruction historique des relations diplomatiques du Brésil avec deux de ses voisins sud-américains. Ce travail a été développé à partir de deux objets d'études : les relations Brésil-Argentine et Brésil-Venezuela pendant les années 80 et 90 . 